\title{
A global ozone climatology from ozone soundings via trajectory mapping: a stratospheric perspective
}

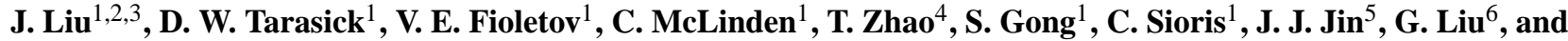 \\ O. Moeini ${ }^{7}$ \\ ${ }^{1}$ Science and Technology Branch, Environment Canada, 4905 Dufferin Street, Downsview, Ontario, M3H 5T3, Canada \\ ${ }^{2}$ Department of Geography and Program in Planning, University of Toronto, 100 St. George Street, Toronto, Ontario, \\ M5S 3G3, Canada \\ ${ }^{3}$ Nanjing University, Nanjing, Jiangsu, 210093, China \\ ${ }^{4}$ Nanjing University of Information Science \& Technology, Nanjing, Jiangsu, 210044, China \\ ${ }^{5}$ Universities Space Research Association, and Global Modeling and Assimilation Office, Goddard Space Flight Center, \\ NASA, Greenbelt, MD, 20771, USA \\ ${ }^{6}$ Space Sciences Laboratory, University of California, Berkeley, California, 94720, USA \\ ${ }^{7}$ Department of Earth and Space Science \& Engineering, York University, 4700 Keele Street, Toronto, Ontario, M3T 1P3, \\ Canada
}

Correspondence to: J. Liu (janejj.liu@utoronto.ca)

Received: 16 May 2013 - Published in Atmos. Chem. Phys. Discuss.: 24 June 2013

Revised: 16 October 2013 - Accepted: 21 October 2013 - Published: 25 November 2013

\begin{abstract}
This study explores a domain-filling trajectory approach to generate a global ozone climatology from relatively sparse ozonesonde data. Global ozone soundings comprising 51898 profiles at 116 stations over 44 yr (1965-2008) are used, from which forward and backward trajectories are calculated from meteorological reanalysis data to map ozone measurements to other locations and so fill in the spatial domain. The resulting global ozone climatology is archived monthly for five decades from the 1960s to the 2000s on a grid of $5^{\circ} \times 5^{\circ} \times 1 \mathrm{~km}$ (latitude, longitude, and altitude), from the surface to $26 \mathrm{~km}$ altitude. It is also archived yearly for the same period. The climatology is validated at 20 selected ozonesonde stations by comparing the actual ozone sounding profile with that derived through trajectory mapping of ozone sounding data from all stations except the one being compared. The two sets of profiles are in good agreement, both overall with correlation coefficient $r=0.991$ and root mean square (RMS) of $224 \mathrm{ppbv}$ and individually with $r$ from 0.975 to 0.998 and RMS from 87 to 482 ppbv. The ozone climatology is also compared with two sets of satellite data from the Satellite Aerosol and Gas Experiment (SAGE) and the Optical Spectrography and InfraRed Imager System (OSIRIS). The ozone climatology compares well with SAGE
\end{abstract}

and OSIRIS data in both seasonal and zonal means. The mean differences are generally quite small, with maximum differences of $20 \%$ above $15 \mathrm{~km}$. The agreement is better in the Northern Hemisphere, where there are more ozonesonde stations, than in the Southern Hemisphere; it is also better in the middle and high latitudes than in the tropics where reanalysis winds are less accurate. This ozone climatology captures known features in the stratosphere as well as seasonal and decadal variations of these features. The climatology clearly shows the depletion of ozone from the 1970s to the mid 1990s and ozone increases in the 2000s in the lower stratosphere. When this climatology is used as the upper boundary condition in an Environment Canada operational chemical forecast model, the forecast is improved in the vicinity of the upper troposphere-lower stratosphere (UTLS) region. This ozone climatology is latitudinally, longitudinally, and vertically resolved and it offers more complete high latitude coverage as well as a much longer record than current satellite data. As the climatology depends on neither a priori data nor photochemical modeling, it provides independent information and insight that can supplement satellite data and model simulations of stratospheric ozone. 


\section{Introduction}

Ozone is an important trace gas in the atmosphere, playing a significant role in atmospheric chemical, dynamical, and radiative processes. In the stratosphere, emissions of humanproduced ozone depleting substances led to a substantial ozone decline that has been reversed by the implementation of the Montreal Protocol in 1987 and its subsequent amendments (World Meteorological Organization (WMO), 2003, 2007). Identifying stratospheric ozone recovery and assessing the impact of ozone changes on climate are important issues that have attracted considerable attention (e.g., Randel and Wu, 1999; Weatherhead and Andersen, 2006; Waugh et al., 2009; Eyring et al., 2010; Ziemke and Chandra, 2012). Stratospheric ozone can also impact chemistry and dynamics in the troposphere, both via direct exchange and the BrewerDobson circulation (e.g., Holton et al., 1995; Stohl et al., 2003) and via effects on planetary wave propagation and global climate (Baldwin and Dunkerton, 2001; Gillett and Thompson, 2003).

An understanding of the distribution of stratospheric ozone and its long-term changes is a critical step to assessing the interactions between ozone variability and climate change. Satellite observations have advantages of consistent quality and global coverage, but suffer from biases between different or successive instruments and limited vertical or horizontal resolution, depending on the measurement approach. Considerable effort has been made previously to develop ozone climatologies, typically combining satellite measurements from one or more instruments with other data sources, often ozonesondes. These data sets are either only meridionally and vertically resolved (two dimensions in latitude and altitude, e.g., Fortuin and Kelder, 1998; Lamsal et al., 2004; McPeters et al., 2007; Randel and Wu, 2007; Hassler et al., 2008; Jones et al., 2009; McLinden et al., 2009; McPeters and Labow, 2012; Bodeker et al., 2013) or of ozone column that is horizontally resolved (two dimensions in latitude and longitude, e.g., Ziemke et al., 2005, 2011). Stratospheric ozone climatologies in two or three dimensions have also been developed from chemistry-climate model simulations (e.g., Eyring et al., 2010; SPARC CCMVal, 2010). Although considerable advances have been made in the past decades to improve model representations of ozone transport and chemistry, uncertainties remain with regard to parameterizations, radiation transport schemes, and simulation of the Brewer-Dobson circulation, as well as predictions of the late-spring breakup of the Antarctic vortex and of the Antarctic ozone hole (e.g., SPARC CCMVal, 2010; Forster et al., 2011; Wang and Waugh, 2012).

In this study, we explore a different approach to develop a long-term ozone climatology (1960s-2000s) from global ozonesonde data for satellite and model a priori, satellite and climate model data validation, troposphere-stratosphere exchange, and atmospheric climate-chemistry interaction research. Ozone soundings have the advantages of long-term and quasi-global coverage, high accuracy, and high vertical resolution but are sparse in space and time. Given ozone's long lifetime of weeks to months in the lower stratosphere (e.g., Jacob, 1999), a measurement of ozone mixing ratio at one place and time generally provides a good estimate of ozone mixing ratio in that same air parcel several days before or after. It is therefore possible to extend sparse ozonesonde measurements and to fill the gaps in the spatial domain by trajectory calculations, assuming the ozone mixing ratio along each trajectory path is constant. This is a technique that has been used successfully with other stratospheric data (Sutton et al., 1994; Newman and Schoeberl, 1995; Morris et al., 2000), and with ozone data in both the stratosphere and troposphere. Stohl et al. (2001) used trajectory statistics to extend one year of MOZAIC (Measurement of Ozone and Water Vapour by Airbus In-service Aircraft) ozone measurements into a 4-season ozone climatology at a $10^{\circ} \times 6^{\circ}$ (longitude by latitude) horizontal grid and three vertical heights. Trajectory mapping has also been used to fill gaps in satellite MLS (Microwave Limb Sounder) ozone data in the stratosphere in order to calculate the tropospheric residual ozone column (Schoeberl et al., 2007). Tarasick et al. (2010) developed high resolution $\left(1^{\circ} \times 1^{\circ} \times 1 \mathrm{~km}\right.$ in latitude, longitude, and altitude) tropospheric ozone fields for North America from ozonesonde data from the INTEX (Intercontinental Transport Experiment) and ARCTAS (Arctic Research of the Composition of the Troposphere from Aircraft and Satellites) campaigns. This has been recently extended to global tropospheric ozonesonde data by Liu et al. (2013).

Our study is aimed at (1) developing a global long-term ozone climatology from ozonesondes in 3 dimensions (latitude, longitude, and altitude), (2) validating this data set against independent ozonesondes and satellite observations, (3) characterizing the stratospheric ozone distribution and its decadal and seasonal variabilities, and (4) illustrating applications of this data set in providing evidence of ozone recovery and in improving simulations of tropospheric ozone.

In the following, Sect. 2 explains the methodology of trajectory mapping and the input ozonesonde data. Section 3 describes the validation of the trajectory-mapped data set with ozonesonde data and the comparisons between this data set and satellite data sets from SAGE (the Satellite Aerosol and Gas Experiment) and OSIRIS (the Optical Spectrography and InfraRed Imager System). In Sect. 4, variations of stratospheric ozone at different timescales are characterized. Section 5 discusses the timing of stratospheric ozone changes based on this ozone climatology, and shows the improvement in the tropospheric ozone simulation made with an air quality forecast model when this climatology is used as the upper boundary condition. Conclusions are provided in Sect. 6 . 


\section{Methods}

\subsection{Global ozonesonde data}

The global ozonesonde data used herein were acquired from the World Ozone and Ultraviolet Radiation Data Centre (WOUDC), which is one of five World Data Centres of the Global Atmosphere Watch programme of the World Meteorological Organization. The WOUDC operates a scientific archive, providing ozone data to the international scientific community (Wardle et al., 1998; Hare et al., 2007). Table 1 describes these stations, including their geolocations (latitude, longitude, and elevation), operation periods, and the total number of profiles used in this study. The stations' geolocations are illustrated in Fig. 1a, showing their nonuniform distribution around the globe. There are more stations in the Northern Hemisphere (NH) than in the Southern Hemisphere (SH), and more stations in Europe and North America than in Asia. Large gaps appear over China and eastern Russia. The total number of available stations is 47 in the 1970s (Fig. 1b). This number gradually increases with time. In the 2000s, there are 57 stations (Fig. 1c) with more coverage in the tropics, South Asia, East Asia, the Arctic, and the Antarctic. Overall, we employ 51898 ozone soundings globally at 111 stations, for different periods (Table 1) over $44 \mathrm{yr}$ from 1965 to 2008.

Most of the profiles are from the electrochemical concentration cell (ECC)-type ozonesonde, which was introduced in the early 1970s and adopted by a majority of stations in the global network by the early 1980s. Virtually all the data in the most recent decade are from ECC sondes. The remainder are from Brewer-Mast (BM) sondes (currently still in use at one site), the Japanese KC96 sonde, and the Indian sonde. Prior to the early 1990s, three stations in Europe (Praha, Lindenberg, and Legionowo) flew the GDR sonde. A majority of the data before 1980 is from BM sondes or similar (both the GDR and Indian sondes are similar in design to the BM sonde). A small amount of data is available for the early 1960s from carbon-iodine sondes (similar to the KC sondes) and from Regener sondes (which operated by the chemiluminescent reaction of ozone with luminol).

When properly prepared and handled, ECC ozonesondes have a precision of 3-5\% (1- $\sigma)$ and an absolute accuracy of about $5 \%$ in the stratosphere (Kerr et al., 1994; Smit et al., 2007; Deshler et al., 2008; Liu et al., 2009). The ozone sensor response time $\left(e^{-1}\right)$ of about $25 \mathrm{~s}$ gives the sonde a vertical resolution of about $100 \mathrm{~m}$ for a typical balloon ascent rate of $4 \mathrm{~m} \mathrm{~s}^{-1}$. Two types of ECC ozonesondes are in current use, the $2 Z$ model manufactured by EnSci Corp. and the 6A model manufactured by Science Pump, with minor differences in construction and some variation in recommended concentrations of the potassium iodide sensing solution and of its phosphate buffer. The maximum variation in stratospheric response resulting from these differences is likely of the order of $2-3 \%$ (Smit et al., 2007). (a) Ozonesonde Stations, 1960s - 2000s

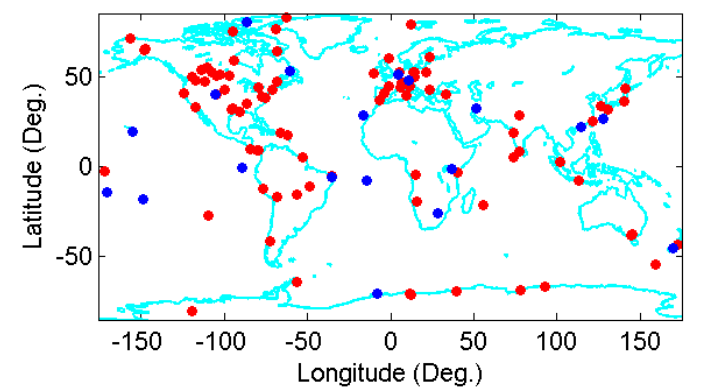

(b) Ozonesonde Stations, 1970s

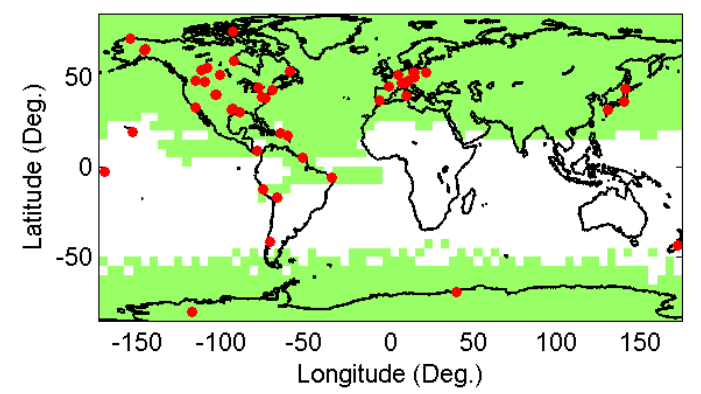

(c) Ozonesonde Stations, 2000s

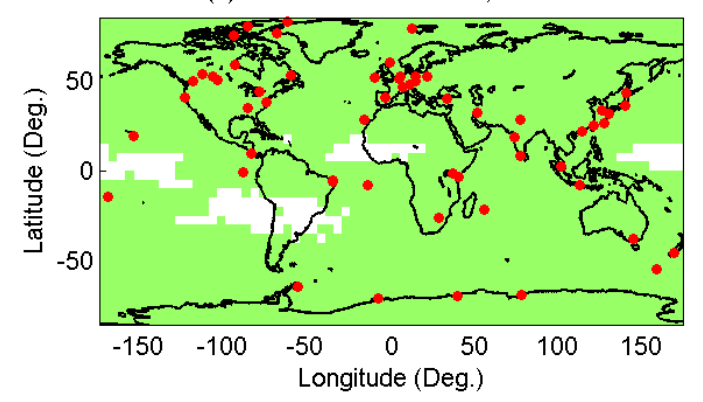

Fig. 1. Global distribution of ozonesonde stations (red and blue dots) used in this study: (a) all stations from the 1960s to the 2000s, (b) in the 1970s, and (c) in the 2000s. Blue dots in (a) indicate stations used for validation (see Table 2). In (b) and (c), the station locations are overlaid with the coverage of ozone climatology (in green) generated in this study at $19.5 \mathrm{~km}$ in the $1970 \mathrm{~s}$ and the 2000s, respectively (see Fig. 12 for the ozone values).

The precision of other sonde types is somewhat poorer, at about 5-10\% (Kerr et al., 1994; Smit et al., 1996). In early intercomparisons (Attmannspacher and Dütsch, 1970, 1981), the Indian and the GDR sonde showed significantly poorer precision than other sonde types.

The largest systematic differences between sondes are in the lower stratosphere, where the BM and GDR sondes gave readings about $5-10 \%$ lower than the ECC and $\mathrm{KC}$ sondes in early intercomparisons (Attmannspacher and Dütsch, 1970, 1981). In later intercomparisons (Kerr et al., 1994; Smit et al., 1996; Deshler et al., 2008), the KC sondes have shown a low bias of about $5 \%$ in the lower stratosphere, and the BM has generally shown a low bias as well. The Indian sonde has generally shown little bias in the lower stratosphere, but 
Table 1. Ozonesonde stations, including each station's ID number, geolocation, the number of profiles used in this study, as well as measurement period.

\begin{tabular}{|c|c|c|c|c|c|c|c|}
\hline Station ID & Station Name & Latitude $\left({ }^{\circ}\right)$ & Longitude $\left(^{\circ}\right)$ & Altitude (m) & Start Year & End Year & No. Profiles \\
\hline 255 & Ainsworth & 42.6 & -100 & 789 & 1986 & 1986 & 7 \\
\hline 229 & Albrook & 9 & -79.6 & 66 & 1980 & 1980 & 20 \\
\hline 18 & Alert & 82.5 & -62.4 & 127 & 1987 & 2008 & 1068 \\
\hline 111 & Amundsen-Scott & -90 & 0 & 2820 & 1965 & 1987 & 272 \\
\hline 348 & Ankara & 40 & 32.9 & 896 & 1994 & 2001 & 167 \\
\hline 328 & Ascension Island & -8 & -14.4 & 91 & 1990 & 2005 & 415 \\
\hline 199 & Barrow & 71.3 & -156.6 & 11 & 1974 & 1974 & 3 \\
\hline 104 & Bedford & 42.5 & -71.3 & 80 & 1969 & 1971 & 77 \\
\hline 181 & Berlin & 52.5 & 13.4 & 50 & 1966 & 1973 & 350 \\
\hline 197 & Biscarrosse/Sms & 44.4 & -1.2 & 18 & 1976 & 1983 & 359 \\
\hline 67 & Boulder & 40.1 & -105.3 & 1689 & 1979 & 1996 & 556 \\
\hline 338 & Bratt's Lake & 50.2 & -104.7 & 592 & 2003 & 2008 & 229 \\
\hline 329 & Brazzaville & -4.3 & 15.3 & 314 & 1990 & 1992 & 82 \\
\hline 394 & Broadmeadows & -37.7 & 144.9 & 108 & 1999 & 2003 & 219 \\
\hline 72 & Byrd & -80 & -119.5 & 1528 & 1965 & 1966 & 59 \\
\hline 38 & Cagliari & 39.3 & 9.1 & 4 & 1968 & 1980 & 419 \\
\hline 108 & Canton Island & -2.8 & -171.7 & 3 & 1965 & 1965 & 31 \\
\hline 20 & Caribou & 46.9 & -68 & 192 & 1981 & 1981 & 1 \\
\hline 444 & Cheju & 33.5 & 126.5 & 300 & 2001 & 2001 & 13 \\
\hline 224 & Chilca & -12.5 & -76.8 & -1 & 1975 & 1975 & 3 \\
\hline 138 & Christchurch & -43.5 & 172.6 & 34 & 1965 & 1965 & 25 \\
\hline 77 & Churchill & 58.8 & -94.1 & 35 & 1973 & 2008 & 1431 \\
\hline 198 & Cold Lake & 54.8 & -110.1 & 702 & 1977 & 1981 & 66 \\
\hline 236 & Coolidge Field & 17.3 & -61.8 & 10 & 1976 & 1976 & 7 \\
\hline 334 & Cuiabá & -15.6 & -56.1 & 990 & 1992 & 1992 & 21 \\
\hline 450 & Davis & -68.6 & 78 & 16 & 2003 & 2005 & 61 \\
\hline 316 & De Bilt & 52.1 & 5.2 & 9.5 & 1994 & 2006 & 650 \\
\hline 238 & Denver & 39.8 & -104.9 & 1611 & 1977 & 1977 & 1 \\
\hline 441 & Easter Island & -27.2 & -109.4 & 62 & 1995 & 1997 & 75 \\
\hline 21 & Edmonton & 53.6 & -114.1 & 766 & 1970 & 2008 & 1562 \\
\hline 456 & Egbert & 44.2 & -79.8 & 253 & 2003 & 2008 & 185 \\
\hline 213 & El Arenosillo & 37.1 & -6.7 & 41 & 1977 & 1983 & 20 \\
\hline 335 & Etosha Pan & -19.2 & 15.9 & 1100 & 1992 & 1992 & 16 \\
\hline 315 & Eureka & 80 & -86.2 & 310 & 1992 & 2008 & 1077 \\
\hline 105 & Fairbanks & 64.8 & -147.9 & 138 & 1965 & 1965 & 47 \\
\hline 438 & Fiji & -18.1 & 178.3 & 6 & 1997 & 2005 & 247 \\
\hline 203 & Ft. Sherman & 9.3 & -80 & 57 & 1977 & 1977 & 16 \\
\hline 228 & Gimli & 50.6 & -97.1 & 228 & 1980 & 1985 & 31 \\
\hline 76 & Goose Bay & 53.3 & -60.4 & 40 & 1965 & 2008 & 1774 \\
\hline 237 & Great Falls & 47.5 & -111.4 & 1118 & 1977 & 1977 & 4 \\
\hline 40 & Haute Provence & 43.9 & 5.7 & 674 & 1981 & 1997 & 61 \\
\hline 477 & Heredia & 10 & -84.1 & 1176 & 2006 & 2006 & 69 \\
\hline 109 & Hilo & 19.6 & -155.1 & 11 & 1965 & 2001 & 679 \\
\hline 99 & Hohenpeissenberg & 47.8 & 11 & 975 & 1966 & 2007 & 4147 \\
\hline 344 & Hong Kong & 22.3 & 114.2 & 66 & 2000 & 2007 & 310 \\
\hline 418 & Huntsville & 34.7 & -86.6 & 196 & 1999 & 2003 & 160 \\
\hline 303 & Iqaluit & 63.8 & -68.6 & 20 & 1991 & 1992 & 30 \\
\hline 437 & Java & -7.6 & 112.7 & 50 & 1998 & 2006 & 264 \\
\hline 265 & Irene & -25.9 & 28.2 & 1524 & 1990 & 2006 & 346 \\
\hline 336 & Isfahan & 32.5 & 51.4 & 1550 & 1999 & 2008 & 101 \\
\hline 404 & Jokioinen & 60.8 & 23.5 & 103 & 1995 & 1998 & 99 \\
\hline 439 & Kaashidhoo & 5 & 73.5 & 1 & 1999 & 1999 & 54 \\
\hline 7 & Kagoshima & 31.6 & 130.6 & 157.5 & 1969 & 2005 & 841 \\
\hline 457 & Kelowna & 49.9 & -119.4 & 456 & 2003 & 2008 & 234 \\
\hline
\end{tabular}


Table 1. Continued.

\begin{tabular}{|c|c|c|c|c|c|c|c|}
\hline Station ID & Station Name & Latitude $\left(^{\circ}\right)$ & Longitude $\left({ }^{\circ}\right)$ & Altitude (m) & Start Year & End Year & No. Profiles \\
\hline 225 & Kourou & 5.3 & -52.7 & 4 & 1974 & 1974 & 3 \\
\hline 149 & $\mathrm{La} \mathrm{Paz}$ & -16.5 & -68 & 3420 & 1965 & 1965 & 10 \\
\hline 436 & La Reunion Island & -21.1 & 55.5 & 24 & 1998 & 2006 & 232 \\
\hline 256 & Lauder & -45 & 169.7 & 370 & 1986 & 2006 & 1270 \\
\hline 254 & Laverton & -37.9 & 144.8 & 21 & 1984 & 1999 & 384 \\
\hline 221 & Legionowo & 52.4 & 21 & 96 & 1979 & 2008 & 1404 \\
\hline 43 & Lerwick & 60.1 & -1.2 & 80 & 1992 & 2001 & 551 \\
\hline 174 & Lindenberg & 52.2 & 14.1 & 112 & 1975 & 2008 & 2074 \\
\hline 235 & Long View & 32.5 & -94.8 & 103 & 1976 & 1976 & 2 \\
\hline 29 & Macquarie Island & -54.5 & 159 & 6 & 1994 & 2003 & 343 \\
\hline 308 & Madrid/Barajas & 40.5 & -3.7 & 650 & 1994 & 2008 & 489 \\
\hline 400 & Maitri & -70.5 & 11.5 & 223.5 & 1994 & 1998 & 94 \\
\hline 448 & Malindi & -3 & 40.2 & -6 & 1999 & 2006 & 87 \\
\hline 233 & Marambio & -64.2 & -56.6 & 196 & 1988 & 2006 & 348 \\
\hline 466 & Natal & -5.4 & -35.3 & 32 & 2002 & 2007 & 177 \\
\hline 227 & McDonald Observatory & 30.7 & -90.9 & 2081 & 1969 & 1969 & 6 \\
\hline 88 & Mirny & -66.6 & 93 & 30 & 1989 & 1991 & 114 \\
\hline 190 & Naha & 26.2 & 127.7 & 27 & 1989 & 2008 & 706 \\
\hline 175 & Nairobi & -1.3 & 36.8 & 1745 & 1996 & 2006 & 398 \\
\hline 219 & Natal & -5.9 & -35.2 & 32 & 1979 & 2000 & 215 \\
\hline 323 & Neumayer & -70.7 & -8.3 & 42 & 1992 & 2008 & 1198 \\
\hline 10 & New Delhi & 28.5 & 77.2 & 247.5 & 1984 & 2006 & 146 \\
\hline 280 & Novolazarevskaya & -70.8 & 11.9 & 110 & 1985 & 1991 & 393 \\
\hline 89 & Ny Alesund & 78.9 & 11.9 & 242.5 & 1990 & 2006 & 1541 \\
\hline 210 & Palestine & 31.8 & -95.7 & 121 & 1975 & 1985 & 163 \\
\hline 156 & Payerne & 46.5 & 6.6 & 491 & 1968 & 2007 & 4776 \\
\hline 217 & Poker Flat & 65.1 & -147.5 & 357.5 & 1979 & 1982 & 40 \\
\hline 187 & Poona & 18.6 & 73.9 & 559 & 1984 & 2003 & 112 \\
\hline 333 & Porto Nacional & -10.8 & -48.4 & 240 & 1992 & 1992 & 15 \\
\hline 242 & Prague & 50 & 14.5 & 304 & 1979 & 2008 & 1242 \\
\hline 131 & Puerto Montt & -41.5 & -72.8 & 5 & 1965 & 1965 & 5 \\
\hline 24 & Resolute & 74.7 & -95 & 40 & 1966 & 2008 & 1649 \\
\hline 297 & S. Pietro Capofiume & 44.7 & 11.6 & 11 & 1984 & 1993 & 98 \\
\hline 191 & Samoa & -14.3 & -170.6 & 82 & 1995 & 2006 & 435 \\
\hline 434 & San Cristóbal & -0.9 & -89.6 & 8 & 1998 & 2006 & 271 \\
\hline 239 & San Diego & 32.8 & -117.2 & 72.5 & 1977 & 1977 & 2 \\
\hline 234 & San Juan & 18.5 & -66.1 & 17 & 1976 & 1976 & 6 \\
\hline 401 & Santa Cruz & 28.4 & -16.3 & 36 & 1996 & 2003 & 320 \\
\hline 12 & Sapporo & 43.1 & 141.3 & 19 & 1969 & 2008 & 1004 \\
\hline 443 & Sepang Airport & 2.7 & 101.7 & 17 & 1998 & 2007 & 235 \\
\hline 132 & Sofia & 42.8 & 23.4 & 588 & 1982 & 1991 & 239 \\
\hline 231 & Spokane & 47.7 & -117.4 & 576 & 1976 & 1976 & 7 \\
\hline 101 & Syowa & -69 & 39.6 & 22 & 1966 & 2008 & 1284 \\
\hline 432 & Tahiti & -18 & -149 & 2 & 1995 & 1999 & 168 \\
\hline 95 & Taipei & 25 & 121.5 & 25 & 2000 & 2001 & 64 \\
\hline 14 & Tateno/Tsukuba & 36.1 & 140.1 & 31 & 1968 & 2008 & 1299 \\
\hline 157 & Thalwil & 46.8 & 8.5 & 515 & 1966 & 1968 & 183 \\
\hline 205 & Thiruvananthapuram & 8.5 & 77 & 60 & 1984 & 2006 & 165 \\
\hline 460 & Thule & 76.5 & -68.7 & 57 & 1991 & 2003 & 248 \\
\hline 65 & Toronto & 43.8 & -79.5 & 198 & 1976 & 1994 & 16 \\
\hline 445 & Trinidad Head & 40.8 & -124.2 & 55 & 1999 & 2001 & 109 \\
\hline 53 & Uccle & 50.8 & 4.4 & 100 & 1965 & 2007 & 4648 \\
\hline 318 & Valentia & 51.9 & -10.3 & 14 & 1994 & 2008 & 352 \\
\hline 257 & Vanscoy & 52.1 & -107.2 & 510 & 1990 & 2004 & 57 \\
\hline 107 & Wallops Island & 37.9 & -75.5 & 13 & 1970 & 2008 & 1280 \\
\hline 64 & Washington & 39 & -77.5 & 84 & 1965 & 1966 & 89 \\
\hline 194 & Yorkton & 51.3 & -102.5 & 504 & 1975 & 1978 & 72 \\
\hline
\end{tabular}


somewhat lower precision than the other non-ECC sondes. Regener sondes were used regularly for only a brief period in the 1960s, as they showed somewhat erratic response (Hering and Dütsch, 1965).

In the middle and upper stratosphere below $26 \mathrm{~km}$, differences in sonde response are small. Overall, between the tropopause and $26 \mathrm{~km}$ the precision of the various sonde types in recent decades is generally within $\pm 5 \%$, and any systematic biases between them or compared to other ozone sensing techniques are smaller than $\pm 5 \%$ (World Climate Research Programme, 1998).

\subsection{Trajectory calculation and global ozone mapping}

To prepare for trajectory modeling, the ozone mixing ratio profile for each sounding was integrated into 26 vertical levels at 1-kilometer resolution from sea level. Ozone measurements above $26 \mathrm{~km}$ were excluded because of their higher uncertainties (e.g., Fioletov et al., 2006). Trajectories for all 26 levels were calculated using the Hybrid Single-Particle Lagrangian Integrated Trajectory (HYSPLIT) model (version 4.9) (Draxler and Hess, 1998; Draxler 1999), available from the Air Resources Laboratory, National Oceanic and Atmospheric Administration (NOAA) (http://www.arl.noaa. gov/HYSPLIT_info.php). HYSPLIT is driven by the reanalysis meteorological data from the National Centers for Environmental Prediction/National Center for Atmospheric Research (NCEP/NCAR) (Kalnay et al., 1996). The reanalysis data have a horizontal resolution of $2.5^{\circ}$ by $2.5^{\circ}$ in latitude and longitude and 17 vertical levels from the surface to $10 \mathrm{hPa}$. The data are available from 1965 to the present. Both forward and backward trajectories for 4 days $(96 \mathrm{~h})$ were calculated every hour for 51898 ozone soundings and the trajectory positions were stored every $6 \mathrm{~h}$.

Ozone mixing ratios in the 26 levels from each sounding were assigned to the corresponding trajectory positions along the forward and backward paths every $6 \mathrm{~h}$ for 4 days ( 32 positions for each level). Then, the trajectory-mapped data were binned at intervals of $5^{\circ}$ latitude and $5^{\circ}$ longitude at each $1 \mathrm{~km}$ altitude and averaged. This bin size is smaller than the typical ozone correlation length in the stratosphere of about 1000-1500 km (Liu et al., 2009). A global ozone climatology of monthly means for each altitude was generated for each decade from the 1960s to the 2000s. The climatology is also archived yearly from 1965 to 2008 at the same horizontal and vertical resolutions. Figure 1 illustrates the improved spatial coverage if trajectory mapping is used. The trajectory mapping greatly spreads out the ozone information along the trajectory paths, increasing the spatial domain to include most of the globe. Two different altitude coordinates were employed for this binning, and so two sets of maps were produced: (1) with vertical coordinate as altitude above sea level, and (2) with vertical coordinate as altitude above ground level. The latter has advantages for some appli- cations, particularly in the troposphere. Examples of ozone data presented in this paper use altitude above sea level.

Most atmospheric models using assimilated meteorological data produce tropopause heights that are more accurate than climatology. Using an ozone climatology that includes a climatological tropopause with such models can produce, in effect, spurious stratospheric intrusions as air in the upper troposphere (when the actual tropopause is high) is assigned stratospheric values of ozone (e.g., Makar et al., 2010). The opposite effect can occur when the actual tropopause is low. For this reason, we generated three ozone climatology data sets. The first data set is a conventional climatology that uses ozonesonde data in both troposphere and stratosphere, while in the second and third data set, the stratospheric ozone climatology and tropospheric ozone climatology were generated separately with trajectories originating exclusively from the stratosphere and the troposphere, respectively. Tropopause height was determined for each profile by the World Meteorological Organization (1992) criterion, that is, the lowest height at which the temperature lapse rate falls to $2{ }^{\circ} \mathrm{C} \mathrm{km}^{-1}$ or less, provided that the average lapse rate for $2 \mathrm{~km}$ above this height is also not more than $2^{\circ} \mathrm{C} \mathrm{km}^{-1}$. Profiles without a defined tropopause were excluded. The explicitly separated troposphere and stratosphere, which overlap in the upper troposphere-lower stratosphere (UTLS) region, are intended to be used for model a priori where an atmospheric model determines the tropopause location itself. This paper focuses on characterization and validation of the first and second data sets, while the tropospheric climatology is discussed in a parallel paper (Liu et al., 2013). Examples of ozone data presented in this paper use the first data set.

Stohl and Seibert (1998) examined the accuracy of trajectories and found that trajectory errors grow with time dramatically. Using Absolute Horizontal Transport Deviation (AHTD) and Absolute Vertical Transport Deviation (AVTD) as measures, they found AHTD for three-dimensional trajectories to be $\sim 200 \mathrm{~km}$ after 2 days, increasing to $\sim 500 \mathrm{~km}$ after 4 days and to $1000 \mathrm{~km}$ after 6 days, while AVTD is $\sim 200,800$, and $1000 \mathrm{~m}$, respectively, after 2, 4, and 6 days for trajectories starting from the stratosphere. Tropospheric trajectories show even larger increases of AHTD and AVTD with time (Stohl and Seibert, 1998). For the current study, trajectories were limited to 4 days, in order to limit trajectory errors.

\section{Validation and comparison with independent ozone observations}

\subsection{Comparison with ozonesonde profiles}

To test the trajectory methodology, the actual ozone profile at selected stations was compared with that produced by the trajectory mapping using the ozone soundings at all stations 
Table 2. Geolocation of the 20 stations for validation.

\begin{tabular}{llrrr}
\hline Station ID & Station Name & Latitude $\left(^{\circ}\right)$ & Longitude $\left(^{\circ}\right)$ & Altitude $(\mathrm{m})$ \\
\hline 328 & Ascension Island & -8 & -14.4 & 91 \\
67 & Boulder & 40.1 & -105.3 & 1689 \\
315 & Eureka & 80 & -86.2 & 310 \\
438 & Fiji & -18.1 & 178.3 & 6 \\
76 & Goose Bay & 53.3 & -60.4 & 40 \\
109 & Hilo & 19.6 & -155.1 & 11 \\
99 & Hohenpeissenberg & 47.8 & 11 & 975 \\
344 & Hong Kong & 22.3 & 114.2 & 66 \\
265 & Irene & -25.9 & 28.2 & 1524 \\
336 & Isfahan & 32.5 & 51.4 & 1550 \\
256 & Lauder & -45 & 169.7 & 370 \\
190 & Naha & 26.2 & 127.7 & 27 \\
175 & Nairobi & -1.3 & 36.8 & 1745 \\
219 & Natal & -5.9 & -35.2 & 32 \\
323 & Neumayer & -70.7 & -8.3 & 42 \\
191 & Samoa & -14.3 & -170.6 & 82 \\
434 & Cristóbal & -0.9 & -89.6 & 8 \\
401 & Santa Cruz & 28.4 & -16.3 & 36 \\
432 & Tahiti & -18 & -149 & 2 \\
53 & Uccle & 50.8 & 4.4 & 100 \\
\hline
\end{tabular}

except the one being compared. Figure $2 \mathrm{a}$ shows examples of such comparison in the $\mathrm{NH}$ winter and summer months (January and July) in the 1990s at four stations: Boulder $\left(40.1^{\circ} \mathrm{N}, 105.3^{\circ} \mathrm{W}, 1689 \mathrm{~m}\right)$, Hohenpeissenberg $\left(47.8^{\circ} \mathrm{N}\right.$, $\left.11.0^{\circ} \mathrm{E}, 975 \mathrm{~m}\right)$, Uccle $\left(50.8^{\circ} \mathrm{N}, 4.0^{\circ} \mathrm{E}, 100 \mathrm{~m}\right)$, and Eureka $\left(80.0^{\circ} \mathrm{N}, 86.2^{\circ} \mathrm{W}, 310 \mathrm{~m}\right)$. The paired profiles shown are in reasonable agreement. Seasonal variation is well captured in the trajectory-derived ozone profiles. The correlation coefficient $(r)$ between the two data sets is between 0.950 and 0.999 . Biases are between -170 and +80 ppbv, while RMS differences range from 60 to 340 ppbv. Corresponding relative differences against ozonesondes are shown in Fig. $2 b$. Above $15 \mathrm{~km}$ in the stratosphere, the differences are generally lower at Hohenpeissenberg and Eureka (a station in the Arctic) than at Uccle and Boulder. The differences are higher in winter $(<25 \%)$ than in summer $(<20 \%)$ except for Boulder $(<40 \%)$. Relative differences are often large near the UTLS, owing to the very strong gradients of ozone concentration with height in this region and the variation of tropopause height among individual soundings.

Globally, twenty stations were selected (Table 2, Fig. 1a), with a range of latitude from $71^{\circ} \mathrm{S}$ (Neumayer) to $80^{\circ} \mathrm{N}$ (Eureka), and longitude from $171^{\circ} \mathrm{W}$ (Samoa) to $178^{\circ} \mathrm{E}$ (Fuji), and in altitude from near sea level (Tahiti) to 1745 $\mathrm{m}$ (Nairobi). There are 10 stations each in the Northern and Southern Hemispheres, while the number of stations is 9 and 11, respectively, in the Eastern and Western Hemispheres.

In Fig. 3, the monthly mean ozone abundance from ozonesonde data at a selected station is compared with that from trajectory mapping without input from the station, for all 20 stations in the 1990s and 2000s. Overall, the correla- tion coefficient between the two data sets is 0.99 . The overall bias is negligible, at $1.2 \mathrm{ppbv}$, while the RMS difference is 224 ppbv. For individual stations, the correlation coefficient ranges between 0.975 and 0.999 and the RMS differences between 87 and 482 ppbv.

\subsection{Comparison with SAGE ozone data}

The satellite instrument SAGE (McCormick et al., 1989) was designed to measure ozone in the stratosphere where most ozone resides. The SAGE mission expanded over $20 \mathrm{yr}$, starting from SAGE I on board AEM2 (Application Explorer Mission) in 1979. SAGE I was in operation until 1981. SAGE II, on board ERBS (Earth Radiation Budget Satellite), was in operation from 1984-2005. SAGE uses the highly accurate solar occultation technique and has a vertical resolution of less than $1 \mathrm{~km}$. Ozone is derived from measurements in the spectral range of $0.385-1.020 \mu \mathrm{m}$ (Cunnold et al., 1989). In the absence of clouds, SAGE can detect some layers in the middle and upper troposphere after a significant improvement in the algorithms (Kent et al., 1993). Wang et al. (2002) compared SAGE II with ozonesonde data and found that SAGE tends to slightly overestimate ozone (less than $5 \%$ ) between 15 and $20 \mathrm{~km}$ altitude and systematically underestimates ozone in the troposphere by approximately $30 \%$ between 2 and $8 \mathrm{~km}$ altitude. This is consistent with the comparisons we made with the trajectory-mapped data in Fig. 4.

This study uses SAGE I version 7.0 and SAGE II version 6.2 (Wang et al., 2006). Vertical profiles are reported in number density at $1 \mathrm{~km}$ resolution from $0.5 \mathrm{~km}$ to $60.5 \mathrm{~km}$. Each profile is matched with temperature and pressure from 

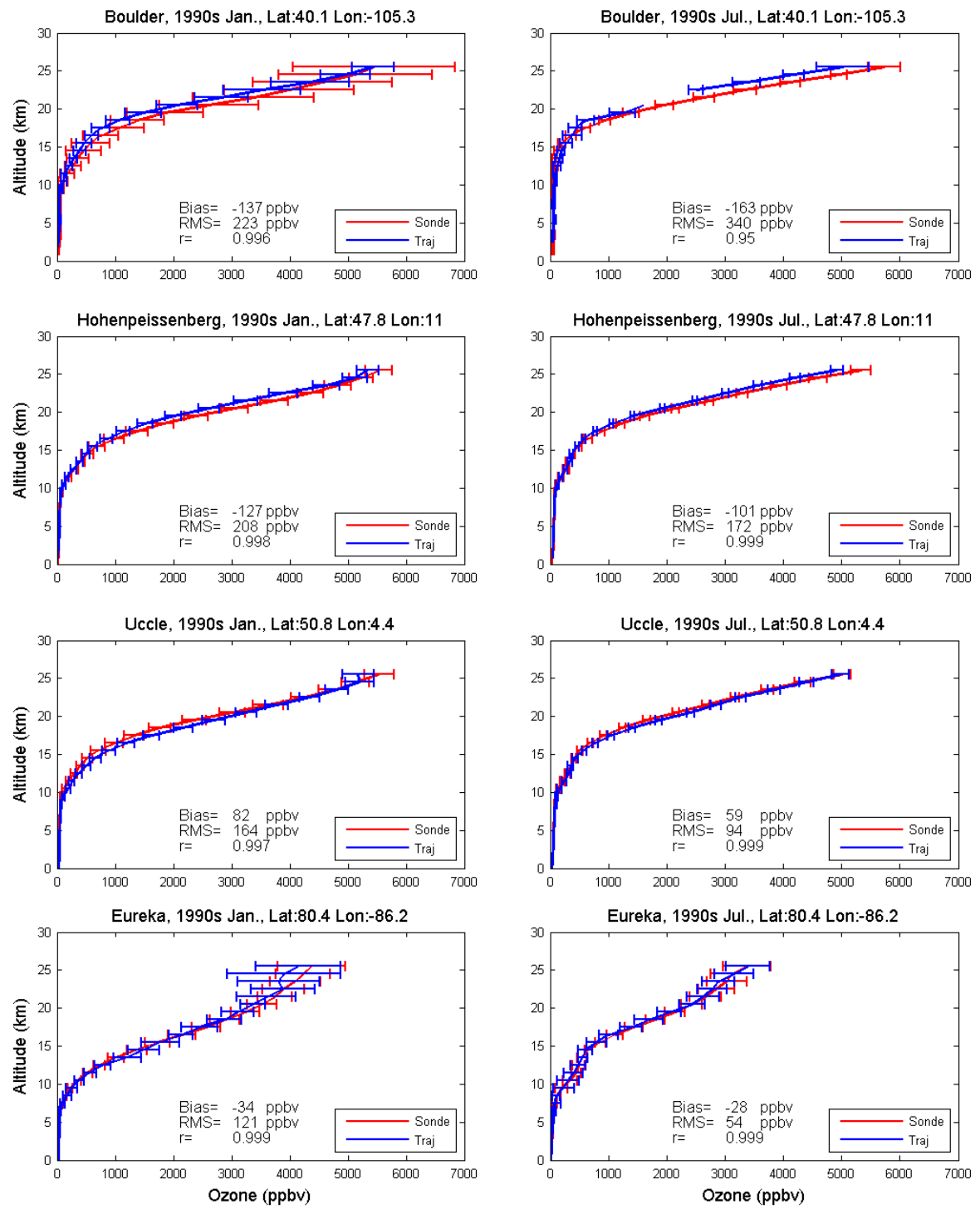

Fig. 2a. Ozone profiles at Boulder, Hohenpeissenberg, Uccle, and Eureka: decadal monthly means in January (left) and July (right) in the 1990s. The actual sounding profiles are labeled "Sonde" in the panels, while the profiles from trajectories without input from the station being tested are labeled "Traj". The error bar is 4 times the standard error of the mean (equivalent to $95 \%$ confidence limits on the averages). The RMS is the root mean square and $r$ is the correlation coefficient.
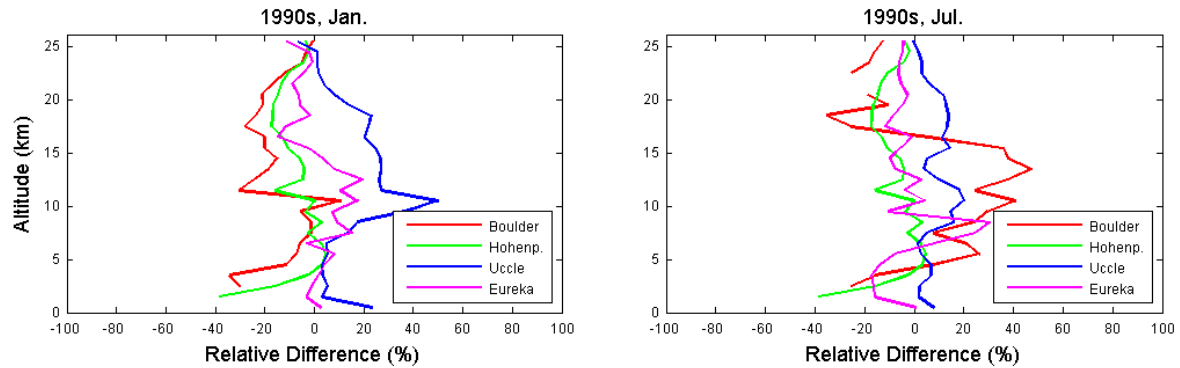

Fig. 2b. Same as Fig. 2a, but showing relative difference against ozonesondes at Boulder, Hohenpeissenberg (Hohenp. in the legend), Uccle, and Eureka in January (left) and July (right) in the 1990s. 


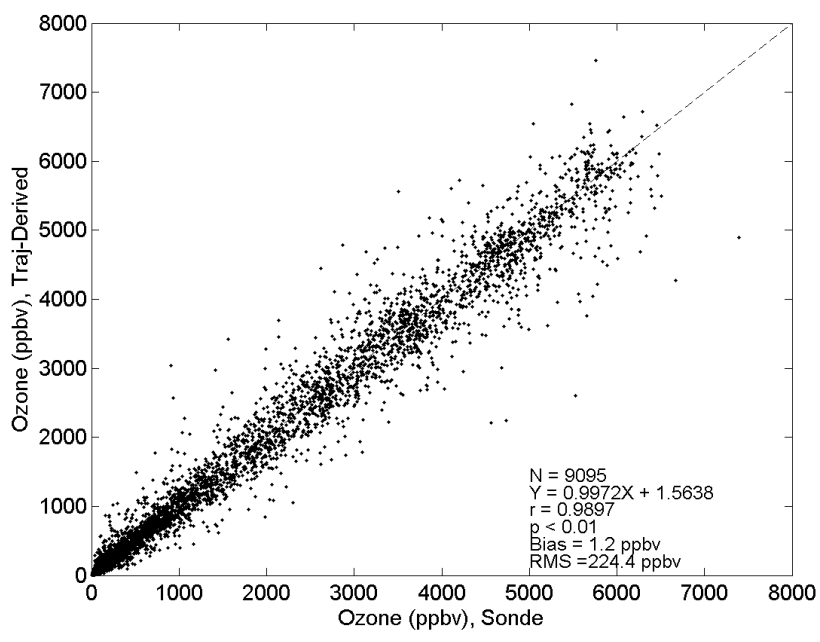

Fig. 3. Correlation $(r)$ between ozone mixing ratios from ozonesondes and from trajectories, without input of the stations being tested, for 20 stations in the 1990s and the 2000s. The dashed line shows the $1: 1$ axis. The correlation is significant at the $1 \%$ level $(p<$ 0.01). $N$ denotes the number of data points and RMS is the root mean square. $Y$ represents trajectory-derived ozone mixing ratio and $X$ ozone mixing ratio from ozonesondes.

NMC/NCEP (National Meteorological Centre/National Centre for Environment Protection) to derive ozone mixing ratio from the surface to $26 \mathrm{~km}$ (McLinden et al., 2009). The comparison with SAGE data is conducted here in two ways.

Firstly, profiles from the ozone climatology were compared with SAGE and ozonesonde data vertically. About 1400 SAGE profiles from 1979 to 2005 that coincided with ozonesonde profiles were extracted. Each pair of SAGE and ozonesonde profiles was matched with the corresponding profile from the ozone climatology in the same month, decade, and $5^{\circ} \times 5^{\circ}$ latitude-longitude bin. That is, the comparisons between ozonesonde and SAGE profiles were made at the same location and time, while ozonesonde profiles were compared with those from the ozone climatology at the same location, month, and decade. Figure 4 shows the vertical distribution of the mean relative differences in the 1990s in NH summer (JJA) and winter (DJF) by four latitudinal zones. Above $15 \mathrm{~km}$, mean differences from the ozone climatology are mostly $<10 \%$, as are SAGE-sonde differences. Below $15 \mathrm{~km}$, the ozone climatology is closer to ozonesondes than SAGE. The distribution of the bias for vertical profiles of SAGE is consistent with previous studies (e.g., Wang et al., 2002; Fioletov et al., 2006). The comparison between the climatology and ozonesondes is better in the summer than in the winter, and better at higher latitudes $\left(45-90^{\circ} \mathrm{N}, 45-\right.$ $\left.90^{\circ} \mathrm{S}\right)$ than at lower latitudes $\left(0-45^{\circ} \mathrm{N}, 0-45^{\circ} \mathrm{S}\right)$. This appears to be largely the case for SAGE as well. To some extent, the difference profiles of the climatology from sondes in Fig. 4 are similar to the corresponding SAGE-sonde dif- ference profiles, which may indicate that they are largely due to sampling issues with the sondes.

Secondly, decadal monthly means from SAGE were gridded at the same 3-dimensional resolution as the ozone climatology $\left(5^{\circ} \times 5^{\circ} \times 1 \mathrm{~km}\right.$ in latitude, longitude, and altitude). The two data sets, which are for the same time period, are compared by grid cell, along with ozonesonde data. Figure 5 compares the three data sets by season, taking data at grid cells where all the data are available in the 1990s and the 2000s.

In general, the trajectory-derived ozone climatology agrees well with ozonesondes (left panels). The scatter is due to imperfections in the wind fields as well as measurement error in the original sonde data. The SAGE-ozonesonde correlation appears reasonably good for the four seasons (middle panels), although the degree of scatter is larger than that for the ozone climatology. The ozone climatology correlates well with SAGE data in all seasons (right panels) with RMS errors that are about the same as the SAGE-sonde comparison (middle panels). Most notable is that the leftmost panels show much less scatter (smaller RMS errors and higher $r$ ) in all seasons than the two comparisons involving SAGE data. Among four seasons, the smallest scatter appears in June-July-August (JJA) for all three comparisons. The trajectory-derived ozone climatology also compares better with ozonesonde and satellite data in JJA than in other seasons (see Fig. 4 and Table 3). This is most likely because geophysical variability is generally lower during this season in the Northern Hemisphere where more sonde measurements are available. In addition, wind speeds in JJA are not as strong as in other seasons, reducing trajectory lengths.

The same data points are divided into six $30^{\circ}$ latitude zones (Fig. 6). The climatology is closely correlated with independent ozonesondes, with $r>0.98$ in all cases. The SAGE-ozonesonde correlations (Fig. 6, right panels) show more scatter than the ozone climatology-ozonesonde correlations in all six latitude zones. As in Fig. 5, the ozone climatology-SAGE correlations (not shown) are similar to the SAGE-sonde correlations. Table 3 lists statistics for the ozone climatology and SAGE data in NH winter and summer seasons and 3 altitudes in the 1990s and the 2000s. Both data sets capture the altitude-dependent seasonal variations. The ozone climatology and SAGE data are well-correlated at $14.5 \mathrm{~km}$ with $r \sim 0.9$. The correlation becomes smaller at higher altitudes. At $19.5 \mathrm{~km}$, the correlation coefficient is $\sim 0.8$ for both winter and summer in the 1990s and the 2000s. At $24.5 \mathrm{~km}$ the correlation is poorer, reflecting the fact that the RMS/mean is lower. The mean ozone mixing ratio from the climatology data set is higher than SAGE at $14.5 \mathrm{~km}$ (similar to the SAGE-sonde bias in Fig. 4) but shows little bias at higher altitudes. The RMS difference between the two data sets decreases with altitude from about $30 \%$ at $14.5 \mathrm{~km}$ to about $15-20 \%$ at $24.5 \mathrm{~km}$.

Figure 7 shows the relative difference $\left(=\left[\mathrm{O}_{3(\mathrm{Clim})}-\right.\right.$ $\left.\mathrm{O}_{3 \text { (SAGE) }}\right] /$ mean $\left[\mathrm{O}_{3(\mathrm{Clim})}, \mathrm{O}_{3 \text { (SAGE) }}\right]$, in \%) in $\mathrm{NH}$ winter and 
(a) $1990 \mathrm{~s}, \mathrm{DJF}, 45 \mathrm{~N}-90 \mathrm{~N}$

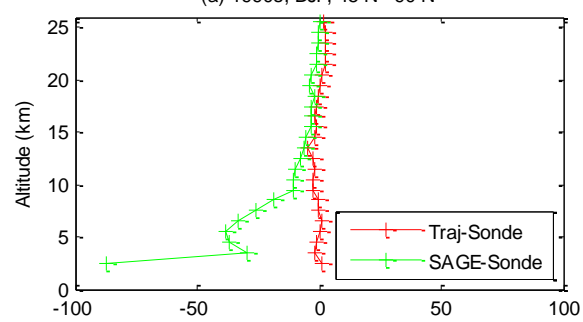

(c) $1990 \mathrm{~s}, \mathrm{DJF}, 0-45 \mathrm{~N}$

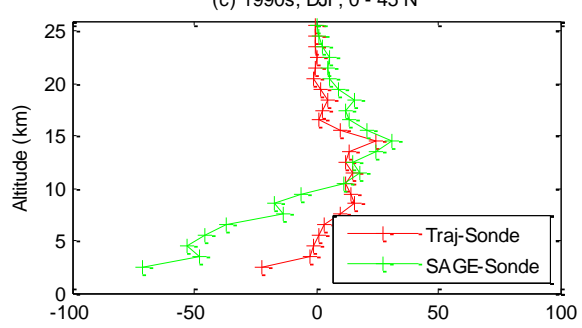

(e) 1990s, DJF, $45 \mathrm{~S}-0$

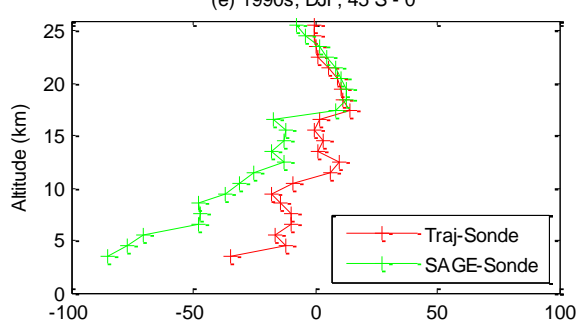

(g) 1990s, DJF, $90 \mathrm{~S}-45 \mathrm{~S}$

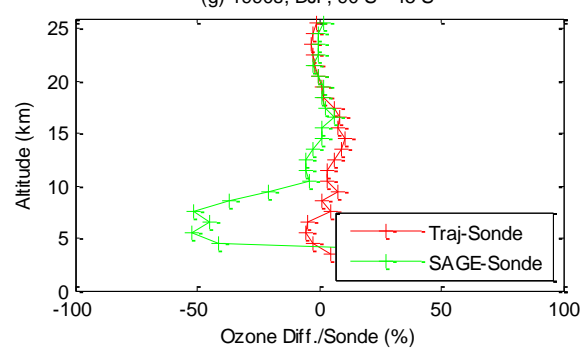

(b) $1990 \mathrm{~s}, \mathrm{JJA}, 45 \mathrm{~N}-90 \mathrm{~N}$

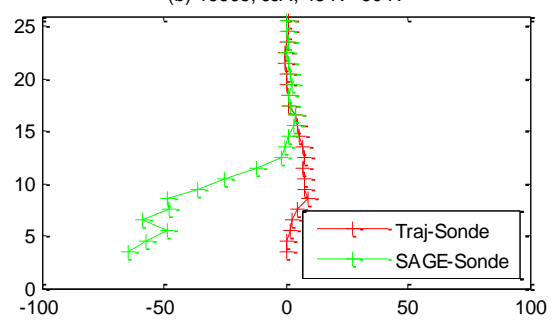

(d) $1990 \mathrm{~s}$, JJA, $0-45 \mathrm{~N}$

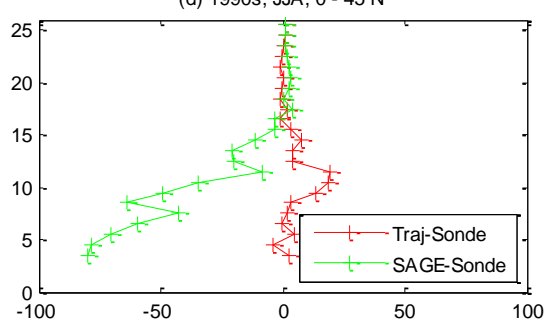

(f) $1990 \mathrm{~s}$, JJA, $45 \mathrm{~S}-0$

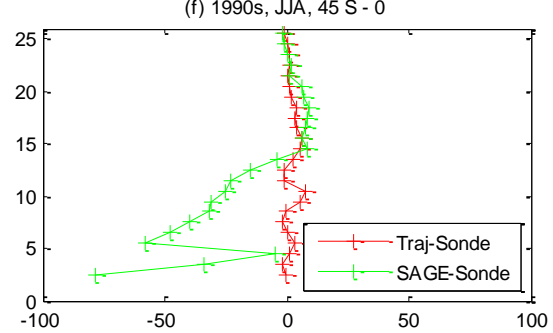

(h) $1990 \mathrm{~s}$, JJA, $90 \mathrm{~S}-45 \mathrm{~S}$

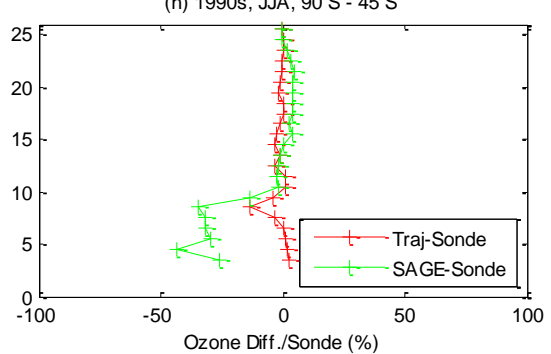

Fig. 4. Mean relative difference between the trajectory-derived ozone climatology and ozonesonde data (in red) for latitude zones $45-90^{\circ} \mathrm{N}$, $0-45^{\circ} \mathrm{N}, 45^{\circ} \mathrm{S}-0^{\circ}$, and $90-45^{\circ} \mathrm{S}$ in $\mathrm{NH}$ winter (DJF, left panels) and summer (JJA, right panels) in the 1990s. Coincident SAGE and ozonesonde profiles are compared in green. See text for details.

summer in the $1990 \mathrm{~s}$ at $19.5 \mathrm{~km}$ and $24.5 \mathrm{~km}$. The comparison covers parts of the globe where both data sets are available. At $19.5 \mathrm{~km}$, the ozone climatology shows significant positive bias relative to SAGE data in several regions, including the region downwind of the east coast of the United States and over the Indian and Atlantic Oceans in the Southern Hemisphere. There are also evident negative biases over mountains in North and South America, Greenland, and the Tibetan region. While the negative biases over mountains may be due to error in the vertical motion fields of the trajectory model, the positive biases noted do not appear to be related to topography. The magnitude of relative differences against SAGE is large at $19.5 \mathrm{~km}$ (ranging from $-100 \%$ to
$100 \%$ ), in part perhaps because the ozone gradient with altitude is the largest here (Fig. 2). At $24.5 \mathrm{~km}$, differences are smaller, ranging from $-40 \%$ to $40 \%$. Differences are smaller in NH summer than in winter (Table 3). A comparison of individual sonde stations to SAGE (not shown) shows similarly large differences from SAGE for some stations in some seasons. This is consistent with Fig. 5, which indicates that SAGE-sonde differences are similar to SAGE-Traj differences. Such large differences could be due to pressurealtitude conversion errors (ozone gradients in the tropics at $19.5 \mathrm{~km}$ are large) at individual stations, or biases due to sampling differences (both sondes and SAGE measurements are sparse and not generally simultaneous). 
(a) $\mathrm{O}_{3}$ (ppbv), DJF

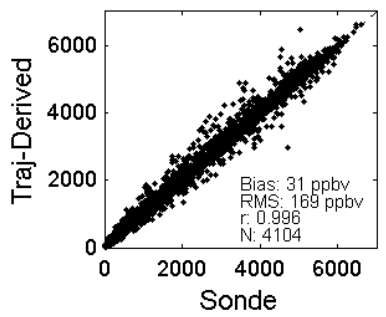

(d) $\mathrm{O}_{3}$ (ppbv), MAM

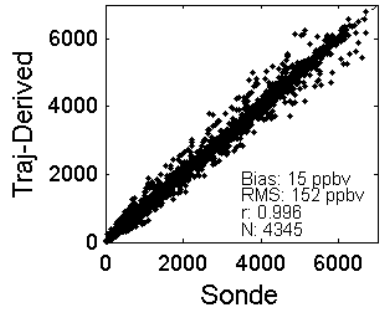

(g) $\mathrm{O}_{3}$ (ppbv), JJA

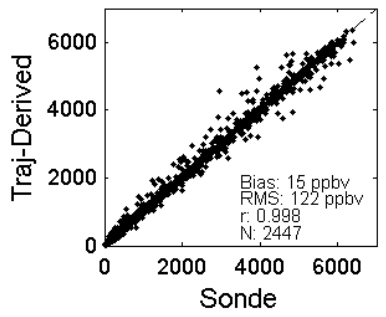

(j) $\mathrm{O}_{3}$ (ppbv), SON

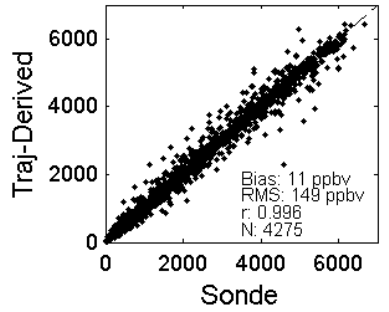

(b) $\mathrm{O}_{3}$ (ppbv), DJF

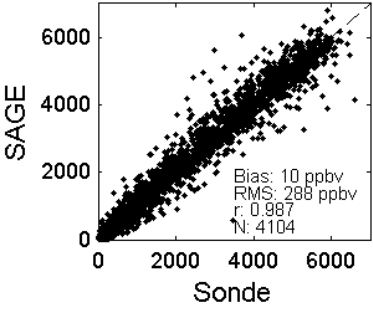

(e) $\mathrm{O}_{3}$ (ppbv), MAM

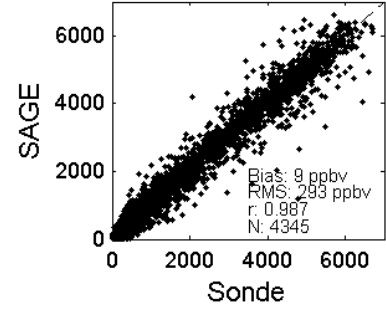

(h) $\mathrm{O}_{3}$ (ppbv), JJA

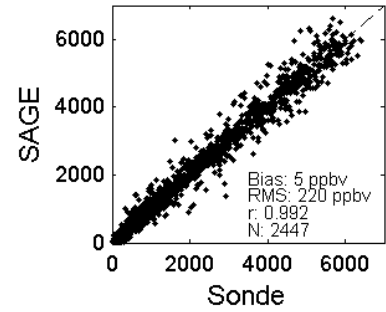

(k) $\mathrm{O}_{3}$ (ppbv), SON

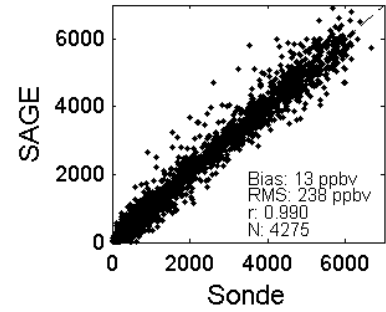

(c) $\mathrm{O}_{3}$ (ppbv), DJF

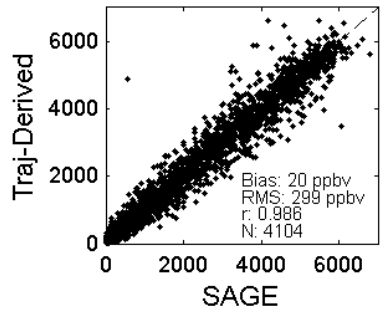

(f) $\mathrm{O}_{3}$ (ppbv), MAM

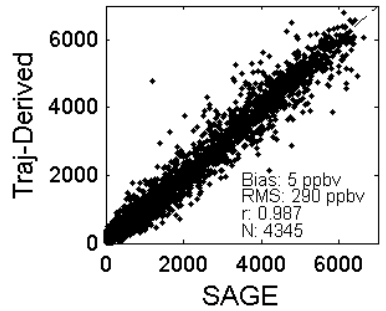

(i) $\mathrm{O}_{3}$ (ppbv), JJA

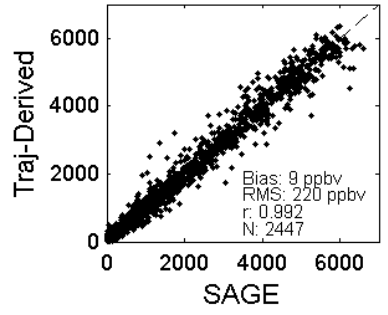

(l) $\mathrm{O}_{3}$ (ppbv), $\mathrm{SON}$

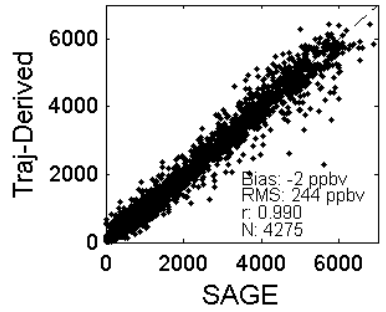

Fig. 5. Correlation $(r)$ of ozone mixing ratio between trajectory-derived, SAGE, and ozonesonde data for the 1990s and 2000s for NH winter (1st row), spring (2nd row), summer (3rd row), and winter (4th row). The dashed line shows the $1: 1$ axis. $N$ denotes the number of data points and RMS is the root mean square. All correlations are significant at a level better than $1 \%$.

\subsection{Comparison with OSIRIS ozone data}

OSIRIS is on board the Swedish/Canadian/French/Finnish Odin satellite, which was launched into a polar, Sunsynchronous orbit at $600 \mathrm{~km}$ in February 2001 (Murtagh et al., 2002; Llewellyn et al., 2004). OSIRIS can scan Earth's limb at tangent heights from 10 to $70 \mathrm{~km}$, covering $82.2^{\circ} \mathrm{S}$ to $82.2^{\circ} \mathrm{N}$. The spectrograph measures scattered sunlight from $280-800 \mathrm{~nm}$, with $\sim 1 \mathrm{~nm}$ spectral resolution. The field of view is about 1.288 arc min in the vertical direction, equivalent to $\sim 1 \mathrm{~km}$ height at the tangent point. The overall accuracy is within $10 \%$ between 15 to $35 \mathrm{~km}$ altitudes (von Savigny et al., 2003). The mean bias of OSIRIS from coinci- dent SAGE measurements is less than $2 \%$ between $18 \mathrm{~km}$ to $53 \mathrm{~km}$ (Degenstein et al., 2009).

From 2002 to 2010, 5900889 data points from OSIRIS were matched with ozone values from this ozone climatology, each pair being in the same month in the 2000s at the same location within the range of a grid $\left(5^{\circ} \times 5^{\circ} \times 1 \mathrm{~km}\right.$ in latitude, longitude, and altitude). The 5900889 pairs of data were compared by season (Fig. 8) and by latitudinal zone (Fig. 9). Overall, the two data sets agree reasonably well (Figs. 8a, 9a and b). By season, the two data sets agree better above $20 \mathrm{~km}$ (relative difference $<10 \%$ ) than lower altitudes (Fig. 8a). The agreement is the best in NH summer and fall (maximum relative difference $<5 \%$ ) and the poorest in winter (maximum relative difference $<20 \%$ ) (Fig. 8a). Both data 
(a) $\mathrm{O}_{3}$ (ppbv), $60 \mathrm{~N}-90 \mathrm{~N}$

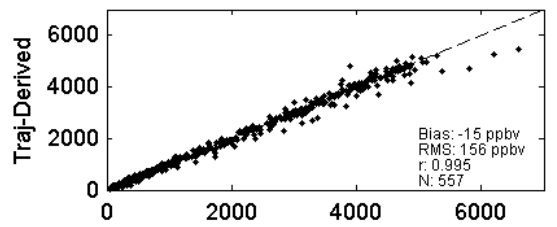

(c) $\mathrm{O}_{3}$ (ppbv), $30 \mathrm{~N}-60 \mathrm{~N}$

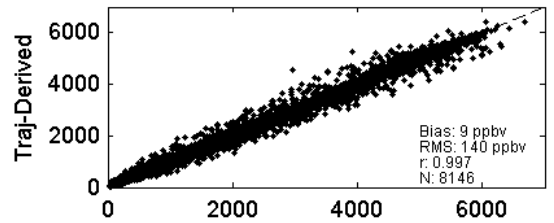

(e) $\mathrm{O}_{3}$ (ppbv), $0-30 \mathrm{~N}$

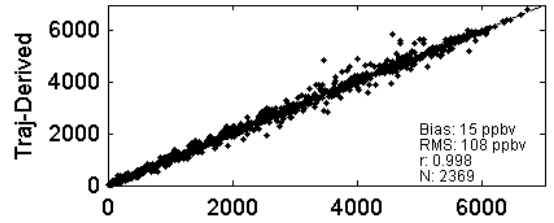

(g) $\mathrm{O}_{3}$ (ppbv), $30 \mathrm{~S}-0$

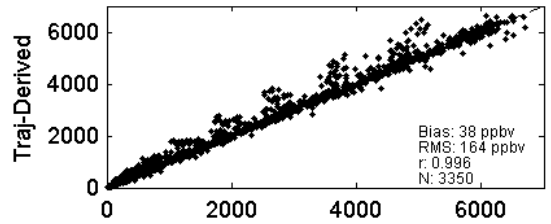

(i) $\mathrm{O}_{3}$ (ppbv), $60 \mathrm{~S}-30 \mathrm{~s}$

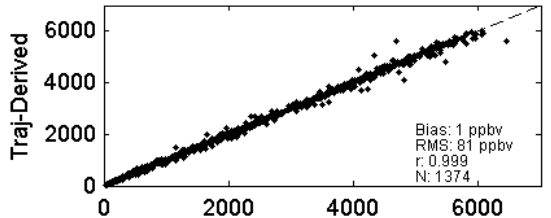

(k) $\mathrm{O}_{3}$ (ppbv), $90 \mathrm{~S}-60 \mathrm{~S}$

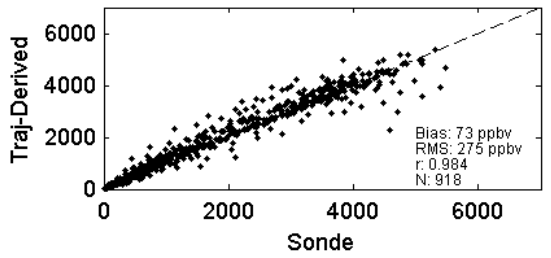

(b) $\mathrm{O}_{3}$ (ppbv), $60 \mathrm{~N}-90 \mathrm{~N}$

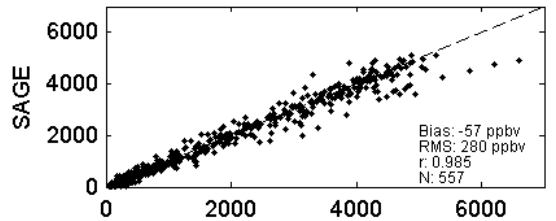

(d) $\mathrm{O}_{3}$ (ppbv), $30 \mathrm{~N}-60 \mathrm{~N}$

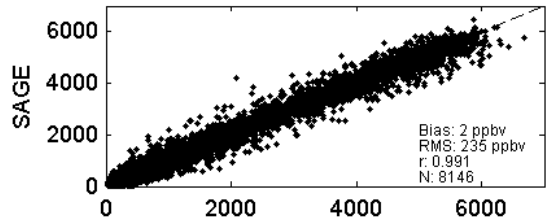

(f) $\mathrm{O}_{3}(\mathrm{ppbv}), 0-30 \mathrm{~N}$

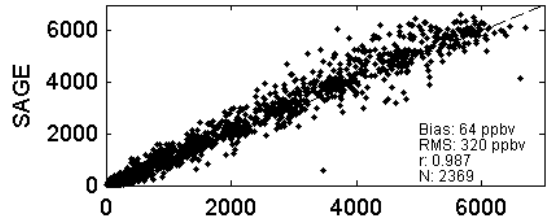

(h) $\mathrm{O}_{3}$ (ppbv), $30 \mathrm{~S}-0$

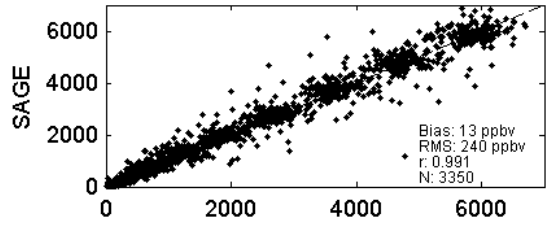

(j) $\mathrm{O}_{3}$ (ppbv), $60 \mathrm{~S}-30 \mathrm{~S}$

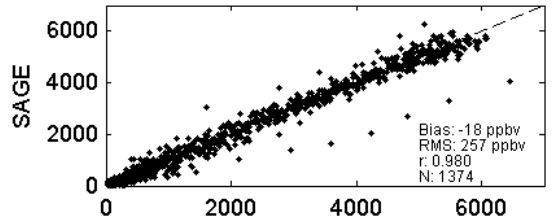

(l) $\mathrm{O}_{3}$ (ppbv), $90 \mathrm{~s}-60 \mathrm{~s}$

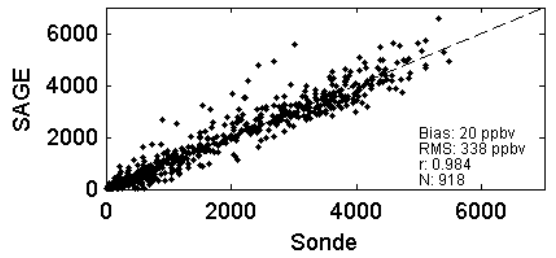

Fig. 6. Correlation $(r)$ of ozone mixing ratio between trajectory-derived and ozonesonde data (left panels) and between SAGE and ozonesonde data (right panels) for the 1990s and 2000s for different latitude zones. The dashed line shows the $1: 1$ axis. $N$ denotes the number of data points and RMS is the root mean square. All correlations are significant at a level better than $1 \%$.

sets can generally capture profile variations with season in both magnitude and profile shape (Fig. $8 \mathrm{~b}$ and c). The largest relative difference $(\approx 20 \%)$ appears in winter over the UTLS region where ozone values from OSIRIS are smaller than those from this ozone climatology (Figs. 8a-c). However, it should be noted that the very strong gradients of ozone concentration with height in this region imply that an altitude bias of as little as $100 \mathrm{~m}$ (which could be introduced by the response time of the ascending ozonesonde) could account for this difference. Examined by latitudinal zone (Fig. 9a and b), the largest relative differences $(\sim 20 \%)$ are found below $20 \mathrm{~km}$, in the $0-45^{\circ}$ latitude range in both hemispheres. The climatology is closer to OSIRIS from $45^{\circ}$ to $90^{\circ} \mathrm{N}$, where there is greater density of sonde data, with a relative difference less than $7 \%$. Global mean profiles for different latitudinal zones are very similar to each other in the two data sets, 
Table 3. Comparison of the ozone climatology and SAGE in the 1990 s and the 2000s at three altitudes in NH winter (DJF) and summer (JJA), respectively. All the correlation coefficients $(r)$ are significant at a significance level $<1 \%(p<0.01) . \mathrm{O}_{3(\mathrm{Clim})}$ and $\mathrm{O}_{3 \text { (SAGE) are the ozone mixing ratios for the climatology and }}$ SAGE data, respectively, averaged over grid cells where both data are available (the number of grid cells is indicated as $N$ ). The RMS is the root mean square difference between the climatology and SAGE data; and RMS/mean is the ratio of the RMS to the mean of $\mathrm{O}_{3(\mathrm{Clim})}$ and $\mathrm{O}_{3 \text { (SAGE) }}$.

\begin{tabular}{|c|c|c|c|c|c|c|}
\hline \multirow[t]{2}{*}{ Variables } & \multicolumn{2}{|c|}{$14.5 \mathrm{~km}$} & \multicolumn{2}{|c|}{$19.5 \mathrm{~km}$} & \multicolumn{2}{|c|}{$24.5 \mathrm{~km}$} \\
\hline & DJF & JJA & DJF & JJA & DJF & JJA \\
\hline \multicolumn{7}{|c|}{$1990 \mathrm{~s}$} \\
\hline $\mathrm{O}_{3(\mathrm{Clim})}(\mathrm{ppbv})$ & 328 & 313 & 1736 & 1584 & 4763 & 4677 \\
\hline $\mathrm{O}_{3 \text { (SAGE) }}(\mathrm{ppbv})$ & 312 & 286 & 1747 & 1640 & 4632 & 4711 \\
\hline $\mathrm{O}_{3 \text { (Clim) })} / \mathrm{O}_{3 \text { (SAGE) }}$ & 1.05 & 1.09 & 0.99 & 0.97 & 1.03 & 0.99 \\
\hline RMS (ppbv) & 104 & 87 & 413 & 337 & 714 & 508 \\
\hline RMS/Mean (\%) & 33 & 29 & 24 & 21 & 15 & 11 \\
\hline$r$ & 0.94 & 0.95 & 0.85 & 0.86 & 0.31 & 0.62 \\
\hline$N$ & 1967 & 1908 & 1633 & 1544 & 1636 & 1579 \\
\hline \multicolumn{7}{|c|}{$2000 \mathrm{~s}$} \\
\hline $\mathrm{O}_{3(\mathrm{Clim})}(\mathrm{ppbv})$ & 323 & 310 & 1698 & 1580 & 4950 & 4817 \\
\hline $\mathrm{O}_{3 \text { (SAGE) }}(\mathrm{ppbv})$ & 306 & 286 & 1702 & 1624 & 4651 & 4737 \\
\hline $\mathrm{O}_{3 \text { (Clim) }} / \mathrm{O}_{3 \text { (SAGE) }}$ & 1.06 & 1.08 & 1.00 & 0.97 & 1.06 & 1.02 \\
\hline RMS (ppbv) & 116 & 105 & 405 & 337 & 819 & 679 \\
\hline RMS/Mean (\%) & 37 & 35 & 24 & 21 & 17 & 14 \\
\hline$r$ & 0.93 & 0.92 & 0.87 & 0.87 & 0.32 & 0.46 \\
\hline$N$ & 1930 & 1904 & 1630 & 1496 & 1584 & 1618 \\
\hline
\end{tabular}

with higher ozone in higher northern and southern latitudes at the same altitude below $23 \mathrm{~km}$ (Fig. 9c and d).

\section{Global ozone distribution}

\subsection{Long-term climatology}

Figure 10 shows the latitude-altitude distribution of the ozone climatology averaged from the 1970 s to the 2000 s. The trajectory mapped ozone climatology can generally capture the steep ozone changes $(<100$ to $>500 \mathrm{ppbv})$ in the vicinity of the tropopause over all latitudes. Near $25 \mathrm{~km}$, the ozone climatology is lower at the poles than at lower latitudes. This distribution is similar to that from SAGE data (e.g., Fioletov, 2008).

The mean ozone distribution from the 1970s to the 2000s at $19.5 \mathrm{~km}$ is shown in Fig. 11a. In order to fill the remaining gaps $(\sim 1 \%)$ and to reduce small-scale "noise", the climatological average values obtained from the mapping are fitted to a linear combination of spherical functions (Fig. 11b). Ozone concentration increases with latitude from $\sim 500 \mathrm{ppbv}$ in the tropics to $\sim 3000 \mathrm{ppbv}$ at the poles, reflecting the influence of the Brewer-Dobson circulation. Moreover, the ozone climatology shows significant longitudinal variation. In the Northern Hemisphere, Fig. 11 shows a wave-like pattern with (a) $1990 \mathrm{~s}, \mathrm{DJF}, 19.5 \mathrm{~km}$

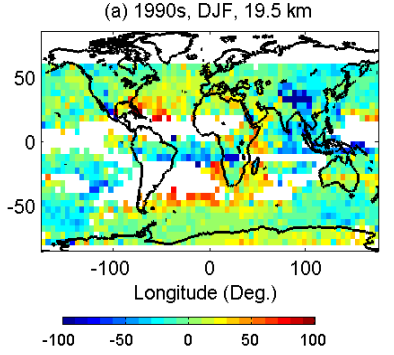

(c) $1990 \mathrm{~s}, \mathrm{DJF}, 24.5 \mathrm{~km}$

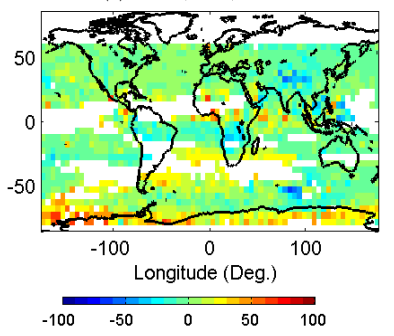

(b) $1990 \mathrm{~s}, J J A, 19.5 \mathrm{~km}$

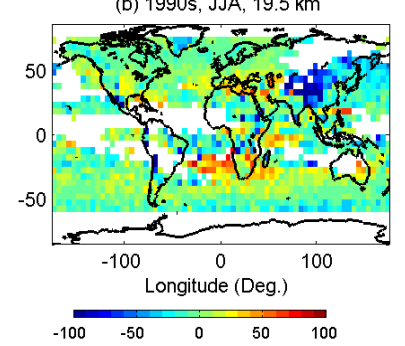

(d) $1990 \mathrm{~s}, J J A, 24.5 \mathrm{~km}$

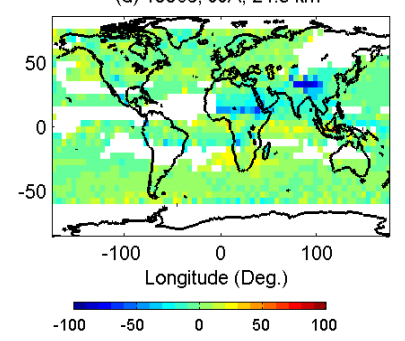

Fig. 7. Relative difference in ozone mixing ratio between the ozone climatology and SAGE data in NH winter (DJF, left panels) and summer (JJA, right panels) in the 1990s at $19.5 \mathrm{~km}$ (upper panels) and $24.5 \mathrm{~km}$ (lower panels). The comparison is made when both data sets are available at a cell and is expressed as the percentage difference of climatology minus SAGE divided by their mean.

high ozone over the northernmost parts of North America and eastern Asia, as also found by Stohl et al. (2001), who attributed this feature to the quasi-permanent troughs over the continents (e.g., Fleagel and Businger, 1980). In the Southern Hemisphere, ozone appears higher over the Antarctic continent.

\subsection{Decadal variability}

The distribution of ozone at $19.5 \mathrm{~km}$ is shown by decade from the 1970s to the 2000s in Fig. 12. The large gaps in the tropics and in the middle latitudes of the Southern Hemisphere in the 1970s are largely filled in by the SHADOZ program (Southern Hemisphere ADditional OZonesondes, Thompson et al., 2003a, b, 2007), starting from the 1990s (Fig. 1b and c).

The global ozone distribution shows some consistent features in the four decades, as described in Sect. 4.1 for the long-term mean. The decadal variability is striking in both hemispheres. Table 4 shows the decadal ozone variation annually, as well as in January and July for the globe, the Arctic $\left(60-90^{\circ} \mathrm{N}\right)$, and the Antarctic $\left(60-90^{\circ} \mathrm{S}\right)$, averaged by only taking values from the grid cells where ozone data are available for all four decades. All regions show ozone depletion from the 1970s to the 1990s and ozone increases in the 2000s. The decadal variation is larger in the winter season than in the summer season in both hemispheres, presumably because of chemical ozone loss in polar winter. 
(a) Relative Difference (\%), 2002-2010

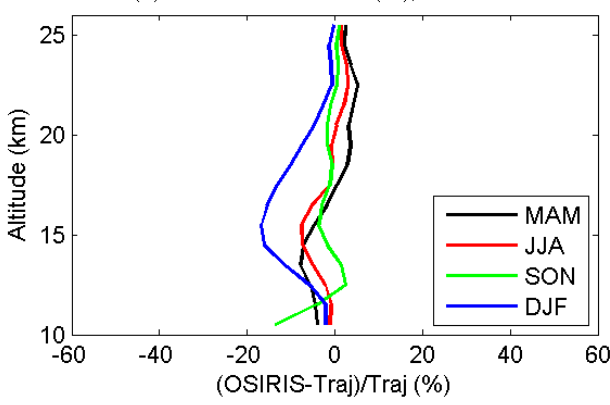

(b) Ozone Climatology, 2002-2010

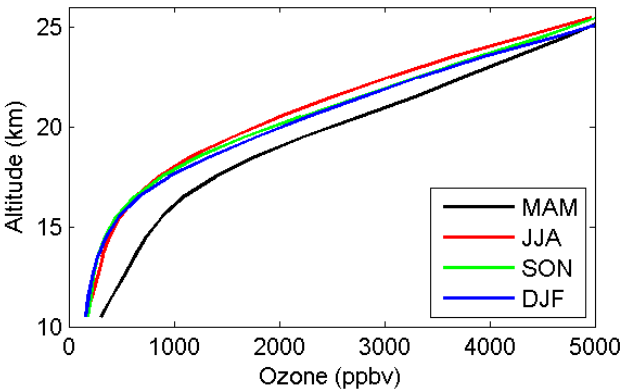

(c) OSIRIS, 2002-2010

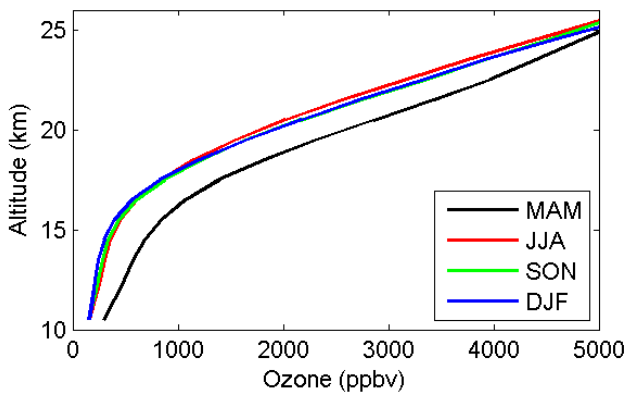

Fig. 8. (a) Relative difference between the trajectory-derived ozone climatology and OSIRIS data in four seasons, (b) global mean ozone profiles from the ozone climatology in four seasons, and (c) global mean ozone profiles from OSIRIS in four seasons (NH spring: MAM, summer: JJA, fall: SON, winter: DJF).

The decadal changes of between -7 and $-9 \%$ per decade in the 1980s and 1990s for the Arctic and -13 to $-14 \%$ per decade for the Antarctic compare well with the trends found by Hassler et al. (2013), who compared three stratospheric ozone data sets, including Randel and Wu (2007), Cionni et al. (2011), and Bodeker et al. (2013). The seasonal changes in the Arctic are also in reasonable agreement with the decadal trends found for the December-JanuaryFebruary (DJF) and June-July-August (JJA) seasons by Hassler et al. (2013). In the Antarctic, however, the trends found by Hassler et al. (2013) are much larger (more negative ) in both DJF and JJA than the decadal changes derived here for January and July. This is in part because December and August are months in which the Antarctic ozone abundances are
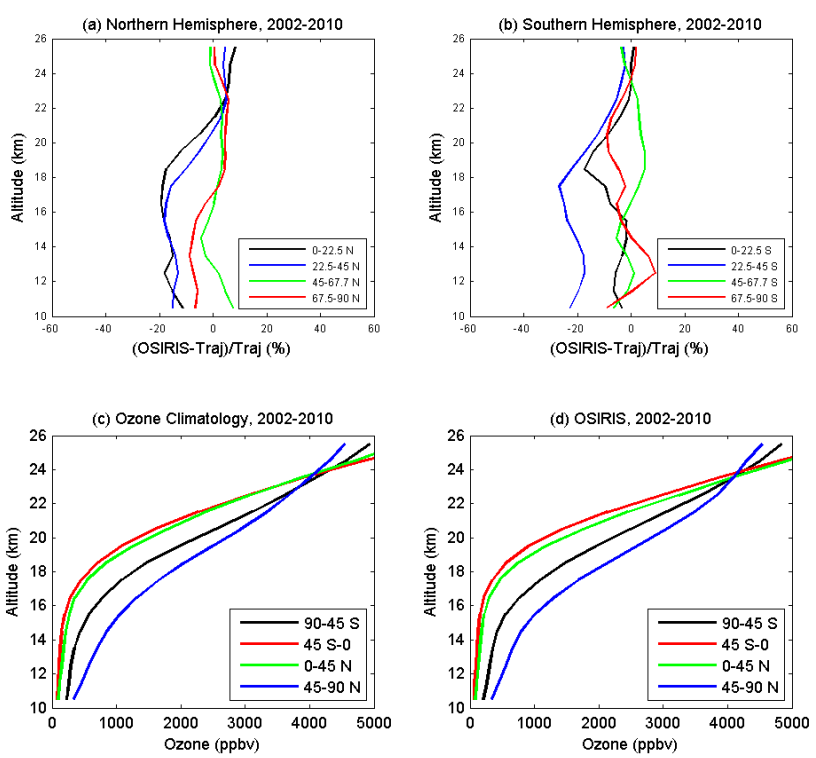

Fig. 9. Relative difference between the trajectory-derived ozone climatology and OSIRIS data in four latitude zones (a) in the Northern Hemisphere and (b) in the Southern Hemisphere. (c) Global mean ozone profiles from the ozone climatology in four latitude zones: $90-45^{\circ} \mathrm{S}, 45^{\circ} \mathrm{S}-0^{\circ}, 0-45^{\circ} \mathrm{N}$, and $45-90^{\circ} \mathrm{N}$. (d) Global mean ozone profiles from OSIRIS in the four zones.

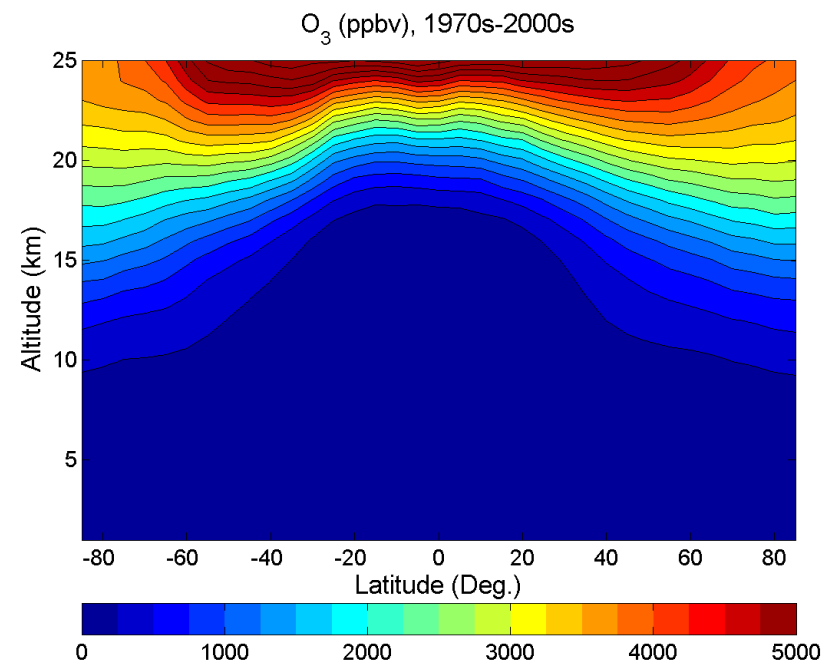

Fig. 10. Long-term latitude-altitude distribution of the ozone climatology (1970s-2000s).

very low, and because Hassler et al. (2013) used $70-90^{\circ} \mathrm{S}$, rather than $60-90^{\circ} \mathrm{S}$, to define the Antarctic region.

Noting that there are large gaps in the tropics as ozone values were taken only from the grid cells where data are available for all four decades, the global decadal changes in Table 4 compare well with other analyses: WMO (2007) reported that the ozone trend over $26-59^{\circ} \mathrm{N}$ at $20 \mathrm{~km}$ is $-5 \%$ per decade between $1980-1996$ and $-3 \%$ per decade 
Table 4. Decadal variability of ozone mixing ratio at $19.5 \mathrm{~km}$ averaged over the globe, the Arctic $\left(60-90^{\circ} \mathrm{N}\right)$, and the Antarctic $\left(60-90^{\circ} \mathrm{S}\right)$ from the 1970 s to the 2000 s in January and July. The mean is area-weighted and is computed by taking values only from grid cells where ozone data are available for all four decades. Therefore, the global means miss large areas in the tropics (see Fig. 12). The change is $\%$ per decade, and relative to the long-term mean.

\begin{tabular}{|c|c|c|c|c|c|c|}
\hline \multirow[b]{2}{*}{ Decade } & \multicolumn{2}{|c|}{ The Globe } & \multicolumn{2}{|c|}{ The Arctic } & \multicolumn{2}{|c|}{ The Antarctic } \\
\hline & $\begin{array}{l}\text { Ozone } \\
\text { (ppbv) }\end{array}$ & $\begin{array}{r}\text { Change } \\
\text { (\% per decade) }\end{array}$ & $\begin{array}{l}\text { Ozone } \\
\text { (ppbv) }\end{array}$ & $\begin{array}{r}\text { Change } \\
(\% \text { per decade })\end{array}$ & $\begin{array}{l}\text { Ozone } \\
\text { (ppbv) }\end{array}$ & $\begin{array}{r}\text { Change } \\
\text { (\% per decade })\end{array}$ \\
\hline & Annual & & & & & \\
\hline $1970 \mathrm{~s}$ & 2382 & & 2976 & & 3125 & \\
\hline $1980 \mathrm{~s}$ & 2199 & -8.5 & 2738 & -8.7 & 2781 & -2.8 \\
\hline $1990 \mathrm{~s}$ & 2015 & -8.5 & 2557 & -6.6 & 2408 & -13.9 \\
\hline $2000 \mathrm{~s}$ & 2033 & 0.8 & 2641 & 3.0 & 2427 & 0.7 \\
\hline \multirow[t]{2}{*}{ Mean } & 2157 & & 2728 & & 2685 & \\
\hline & January & & & & & \\
\hline $1970 \mathrm{~s}$ & 2665 & & 3578 & & 2772 & \\
\hline $1980 \mathrm{~s}$ & 2534 & -5.3 & 3308 & -8.3 & 2753 & -0.7 \\
\hline $1990 \mathrm{~s}$ & 2297 & -9.6 & 3044 & -8.1 & 2592 & -6.0 \\
\hline $2000 \mathrm{~s}$ & 2375 & 3.2 & 3108 & 2.0 & 2656 & 2.4 \\
\hline \multirow[t]{2}{*}{ Mean } & 2468 & & 3260 & & 2693 & \\
\hline & July & & & & & \\
\hline $1970 \mathrm{~s}$ & 2066 & & 2364 & & 3519 & \\
\hline $1980 \mathrm{~s}$ & 1905 & -8.5 & 2179 & -8.4 & 3323 & -6.0 \\
\hline $1990 \mathrm{~s}$ & 1820 & -4.5 & 2085 & -4.3 & 3096 & -6.9 \\
\hline $2000 \mathrm{~s}$ & 1805 & -0.8 & 2164 & 3.6 & 3137 & 1.3 \\
\hline Mean & 1899 & & 2198 & & 3269 & \\
\hline
\end{tabular}

between 1980-2004, updated from Logan et al. (1999). Randel et al. (1999) also found annual mean trends of $-6 \%$ to $-7 \%$ per decade at $20 \mathrm{~km}$ over $40-53^{\circ} \mathrm{N}$ for the period 1979-1996 from ozonesonde and SAGE data.

\subsection{Seasonal variability}

Figure 13 shows the seasonal variability of ozone in the $1990 \mathrm{~s}$ at $19.5 \mathrm{~km}$, demonstrating that there are sufficient data to separate the seasonal variability. The seasonal variation at this level resembles the variation in total ozone (e.g., Fioletov, 2008). The latitudinal gradient (lower ozone in the equator and higher ozone in the middle and high latitudes) is well captured with a maximum in winter and a minimum in summer in the Northern Hemisphere. In the Southern Hemisphere, the latitudinal gradient is the largest in SH fall (MAM), although also nearly as large in winter (JJA), while the minimum occurs in spring (SON) because of Antarctic ozone loss. In the Northern Hemisphere, the maximum latitudinal difference in ozone averaged over all longitudes at $19.5 \mathrm{~km}$ is $2441,2255,1534$, and $1797 \mathrm{ppbv}$ in $\mathrm{NH}$ winter, spring, summer, and fall, respectively, in the smoothed ozone maps, whereas in the Southern Hemisphere, it is 2420, 1900, 2236, and 2512 ppbv in SH winter, spring, summer, and fall, respectively.
In the Northern Hemisphere, the spring ozone maximum over the Canadian Arctic is evident. Another high ozone region in the winter and spring is located over northernmost eastern Asia. This is more obvious in the 2000s (not shown), because of ozone increases in the stratosphere. Both maxima can be also partly seen in the SAGE data up to $60^{\circ} \mathrm{N}$ (not shown). In the Southern Hemisphere, ozone starts to accumulate over the South Pole in SH summer (DJF), gradually increases in abundance and area in SH fall (MAM) and reaches a maximum in SH winter (JJA). In SH spring (SON), with photochemistry destruction of ozone, ozone over the South Pole reaches a minimum, leaving a band of high ozone between $30^{\circ}$ and $60^{\circ} \mathrm{S}$. This feature is reflected in the dip in the ozone contours at $30-55^{\circ} \mathrm{S}$ in Fig. 10 above $20 \mathrm{~km}$. It should be regarded with caution, however, as there are relatively few ozone sounding stations in this latitude range (Fig. 1), and so most of the information comes via relatively long trajectories, with correspondingly larger uncertainties (see also Fig. 14). In addition, the lack of radio sounding stations in this region must also increase the relative uncertainty in the winds in the NCEP database that are used to calculate trajectories. Nevertheless, we note that a similar dip in the ozone contours is seen between $40-60^{\circ} \mathrm{N}$, where ozonesonde data are most abundant. The smoothed ozone fields shown in the right panels of Fig. 13 are gap-filled and have reduced 
Table 5. Standard error of the mean (SE/mean, in \%), coverage (in \% of the total grid cells), and the number of samples per grid (in count/grid) by decade at 19.5 and $24.5 \mathrm{~km}$, respectively.

\begin{tabular}{lrrr|rrr}
\hline & \multicolumn{3}{c|}{$19.5 \mathrm{~km}$} & \multicolumn{3}{|c}{$24.5 \mathrm{~km}$} \\
\cline { 2 - 7 } Decade & $\begin{array}{r}\text { SE/Mean } \\
(\%)\end{array}$ & $\begin{array}{r}\text { Coverage } \\
(\%)\end{array}$ & count/grid & $\begin{array}{r}\text { SE/Mean } \\
(\%)\end{array}$ & $\begin{array}{r}\text { Coverage } \\
(\%)\end{array}$ & count/grid \\
\hline $1970 \mathrm{~s}$ & 6.3 & 33.5 & 20 & 3.9 & 30 & 22 \\
$1980 \mathrm{~s}$ & 7.1 & 51.7 & 18 & 5.0 & 46.1 & 19 \\
$1990 \mathrm{~s}$ & 6.1 & 74.3 & 26 & 3.9 & 72.8 & 26 \\
$2000 \mathrm{~s}$ & 6.4 & 72.4 & 23 & 4.0 & 72.8 & 22 \\
\hline
\end{tabular}

(a) Ozone (ppbv), 1970s-2000s, $19.5 \mathrm{~km}$

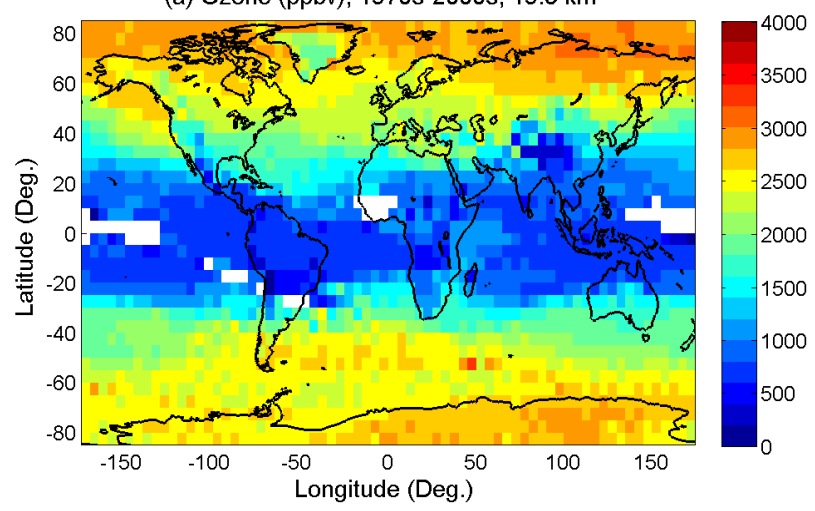

(b) Gap-filled and Smoothed Ozone (ppbv), 1970s-2000s, 19.5 km

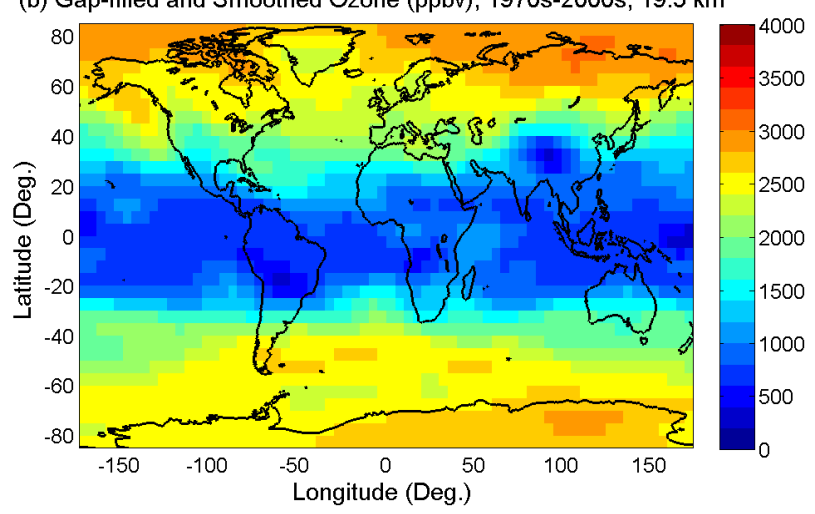

Fig. 11. (a) Long-term ozone climatology (1970s-2000s) at 19.5 $\mathrm{km}$ with gaps (white areas). (b) The gaps are filled and the ozone field is smoothed by a spherical function-based interpolation.

small-scale variation and reduced extrema. Seasonal variability in the 2000s (not shown) is similar to that in the 1990s.

\subsection{Data coverage and standard errors}

As shown in Fig. 12, the trajectory-mapped coverage is improved after the $1980 \mathrm{~s}$. The coverage at $19.5 \mathrm{~km}$ averaged over 12 months is $34 \%$ in the $1970 \mathrm{~s}$, increasing to $52 \%$ in the 1980 s and to $\sim 70 \%$ in the 1990 s and the 2000s (Table 5).
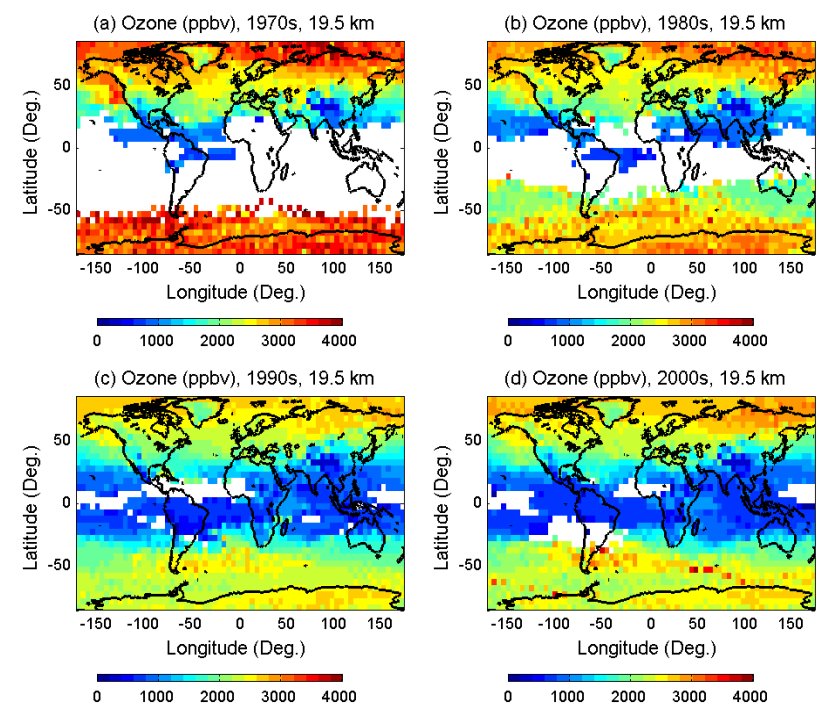

Fig. 12. Decadal variation in ozone at $19.5 \mathrm{~km}$ for (a) the $1970 \mathrm{~s}$, (b) the $1980 \mathrm{~s}$, (c) the 1990s, and (d) the 2000s. White areas indicate missing data.

The coverage at higher or lower altitudes is about the same as at this altitude.

The average number of samples is around 20-25 per grid cell and there are no large differences in this number between decades or among layers. The averaged standard error is about $6-7 \%$ of the mean at $19.5 \mathrm{~km}$ and about $4-5 \%$ of the mean at $24.5 \mathrm{~km}$. Note that standard error is calculated simply from all data points in a grid cell. Depending on the wind speed, some cells may contain more than one value from an individual trajectory, and so the standard error calculation will be biased low.

Seasonally, most missing data are in low latitudes (Fig. 14). In NH summer, data are also missing over northeast Asia. In SH summer (DJF), there are large gaps over South America and the Atlantic Ocean and some regions in the eastern Pacific Ocean. As there are more stations in North America and Europe (Fig. 1), the number of samples per cell is the largest over these regions. In NH winter, there is a band at mid-latitudes $\left(40-70^{\circ} \mathrm{N}\right)$ with a large number of 
(a) Ozone (ppbv). 1990s. D.JF $195 \mathrm{~km}$
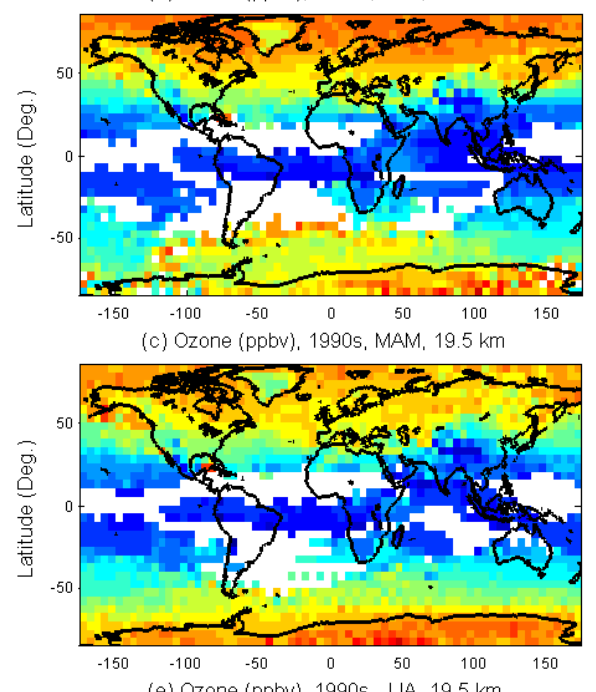

(e) Ozone (ppbv), 1990s, JJA, $19.5 \mathrm{~km}$

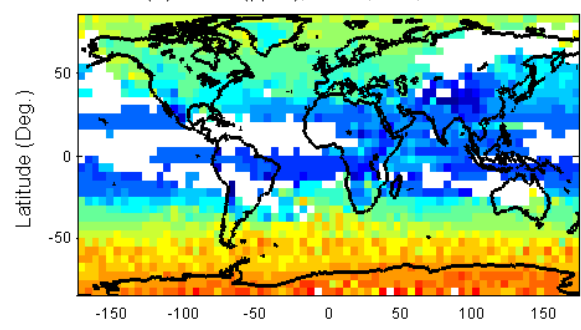

(g) Ozone (ppbv), 1990s, SON, $19.5 \mathrm{~km}$

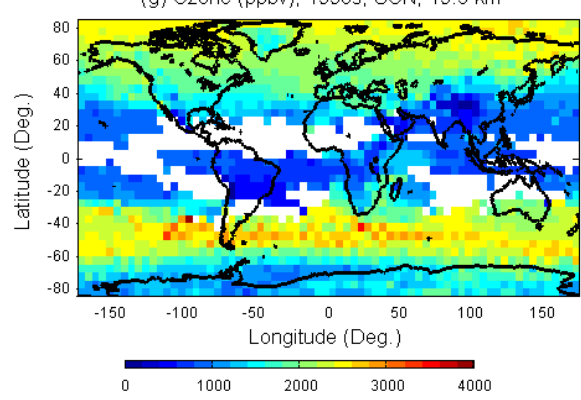

(b) Ozone (ppbv), 1990s, D.JF, $19.5 \mathrm{~km}$
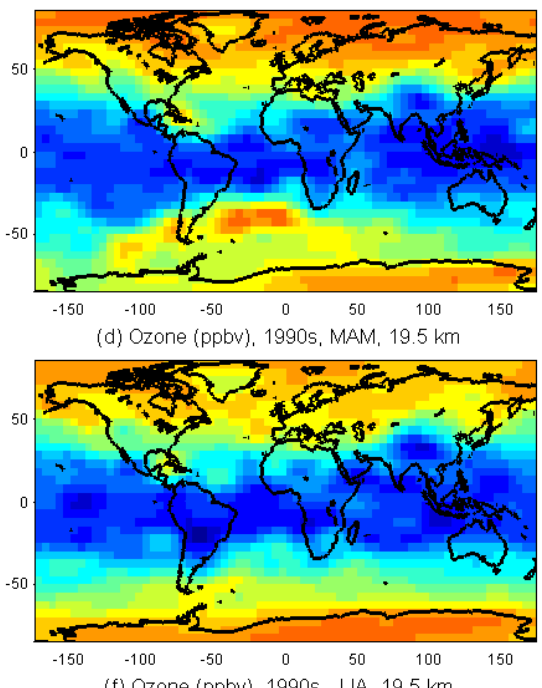

(f) Ozone (ppbv), 1990s, JJA, $19.5 \mathrm{~km}$

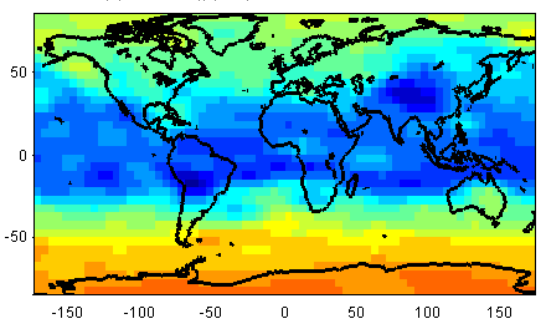

(h) Ozone (ppbv), 1990s, SON, $19.5 \mathrm{~km}$

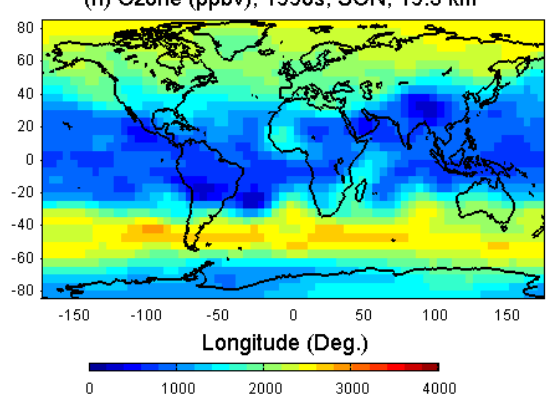

Fig. 13. Ozone fields with gaps (white areas) in the NH winter (DJF), spring (MAM), summer (JJA), and fall (SON) at $19.5 \mathrm{~km}$ in the $1990 \mathrm{~s}$ (left panels) and the corresponding smoothed ozone fields (right panels).

samples. Consequently, the standard error of the mean is low in the region. In the Southern Hemisphere between $40-70^{\circ} \mathrm{S}$, with fewer stations, the standard errors are higher due to the smaller number of samples.

This ozone climatology was generated with 4-day forward and backward trajectories. We also explored 6 day trajectories and found a general increase in data coverage and a slight decrease in the standard error in the stratosphere with the 6day runs. For example, at $19.5 \mathrm{~km}$ in January, the coverage increases from $68 \%$ to $80 \%$ and the mean standard error decreases from $4.8 \%$ to $4.7 \%$. Trajectory errors in the troposphere are larger, however, and the ozone lifetime is shorter (especially in the boundary layer) so 4 day trajectories were used throughout this study. Future studies may use additional data sources (e.g., SAGE, OSIRIS, and MOZAIC data) and improved trajectory methods (e.g., using various time lengths in the stratosphere and troposphere) to eliminate data gaps and enhance accuracy. Some of this work is in progress.

\section{Applications}

In the following we present two examples of applications of this ozone data set. 

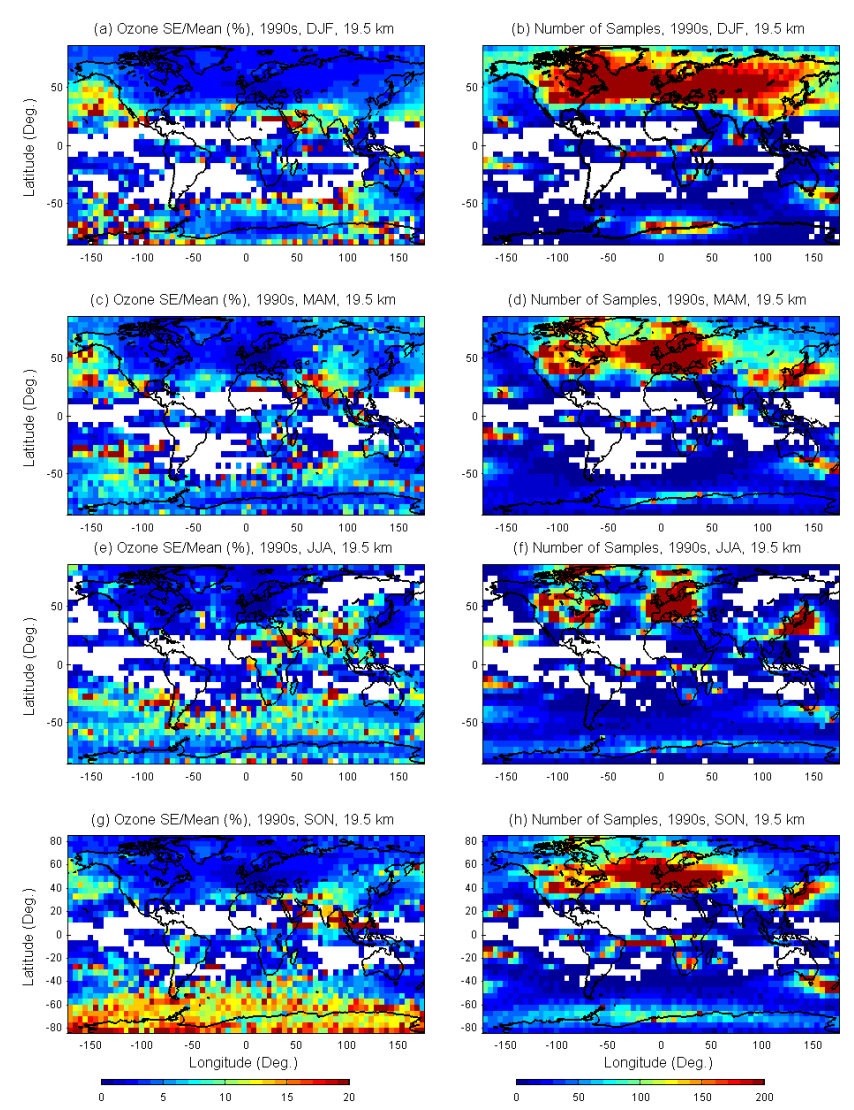

Fig. 14. The standard error of the mean (left panels) and number of samples (right panels) in the NH winter (DJF), spring (MAM), summer (JJA), and fall (SON) in the 1990s at $19.5 \mathrm{~km}$.

\subsection{Stratospheric ozone changes}

Following the implementation of the Montreal Protocol and its amendments, there has been considerable interest in tracking the expected recovery of stratospheric ozone, including the dates when ozone may return to its 1960 and 1980 levels and to a full ozone recovery, i.e., no longer influenced by human-produced ozone depleting substances (ODSs) (e.g., Weatherhead and Andersen, 2006; Shepherd and Jonsson, 2008; Waugh et al., 2009; Eyring et al., 2010; Ziemke and Chandra, 2012). Ozone recovery remains a challenging issue because of the complexity of the natural variability of ozone, as well as the complex impact of greenhouse-gas induced climate change and the removal of atmospheric ODSs owing to the Montreal Protocol. Eyring et al. (2010) analyzed results from 17 chemistry-climate models and predicted that global stratospheric ozone will return to its 1980 and 1960 levels by $\sim 2025$ and $\sim 2040$ respectively. Ziemke and Chandra (2012) suggested an earlier recovery of stratospheric ozone on the basis of their analysis of OMI (Ozone Monitoring Instrument) satellite data. Some studies have suggested that ozone recovery would more likely be at higher latitudes than
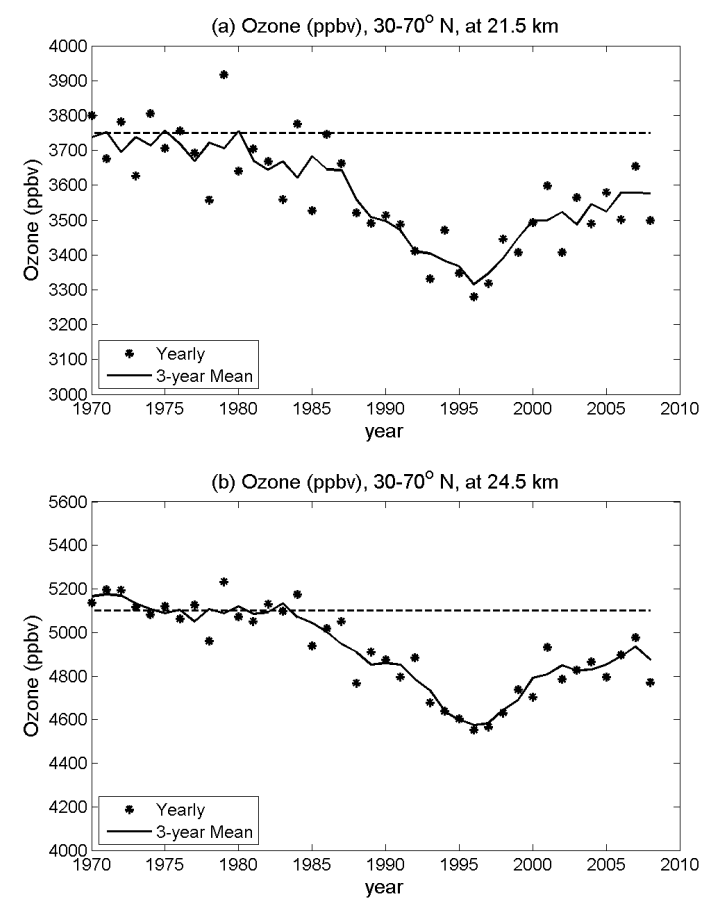

Fig. 15. Annual mean time series at (a) $21.5 \mathrm{~km}(\sim 50 \mathrm{hPa})$ and (b) $24.5 \mathrm{~km}(\sim 30 \mathrm{hPa})$ averaged over $30-70^{\circ} \mathrm{N}$. The solid line is a $3 \mathrm{yr}$ running mean and the dashed line indicates the average ozone level before 1980. The area-weighted average is taken using data only from the grid cells where ozone data are available for all years.

lower latitudes (Weatherhead and Andersen, 2006; Ziemke and Chandra, 2012).

Here we analyze ozone time series in the stratosphere using the yearly averaged ozone climatology. Only data from grid points where ozone values are available for all years from 1970 to 2008 are employed to avoid biases due to data sampling. Using this criterion, the Northern Hemisphere from $30^{\circ} \mathrm{N}$ to $70^{\circ} \mathrm{N}$ is a region with data coverage of about $70 \%$. Data coverage in other regions is somewhat lower. Figure 15 shows the annual area-weighted mean ozone between $30^{\circ} \mathrm{N}$ and $70^{\circ} \mathrm{N}$ at $21.5 \mathrm{~km}(\sim 50 \mathrm{hPa})$ and $24.5 \mathrm{~km}$ $(\sim 30 \mathrm{hPa}$ ), along with corresponding $3 \mathrm{yr}$ running means. Ozone depletion before the mid-1990s is evident at both levels (as well as in between, not shown). The minimum at both levels is in 1996. This figure is quite similar to Fig. 16a of Ziemke and Chandra (2012), which also shows ozone apparent recovery starting from the mid-1990s. The shape of the ozone variation in Fig. 15a is also similar to Fig. 2c of Waugh et al. (2009) in a simulation. Weatherhead and Andersen (2006) merged total column ozone data from TOMS (Total Ozone Mapping Spectrometer) and SBUV/2 (Solar Backscattered Ultraviolet) satellite instruments and found the lowest ozone values during $1993-1997$ over $30^{\circ} \mathrm{N}$ to $80^{\circ} \mathrm{N}$, which also is similar to our results. Their results imply faster recovery in the northern part of the Northern Hemisphere 

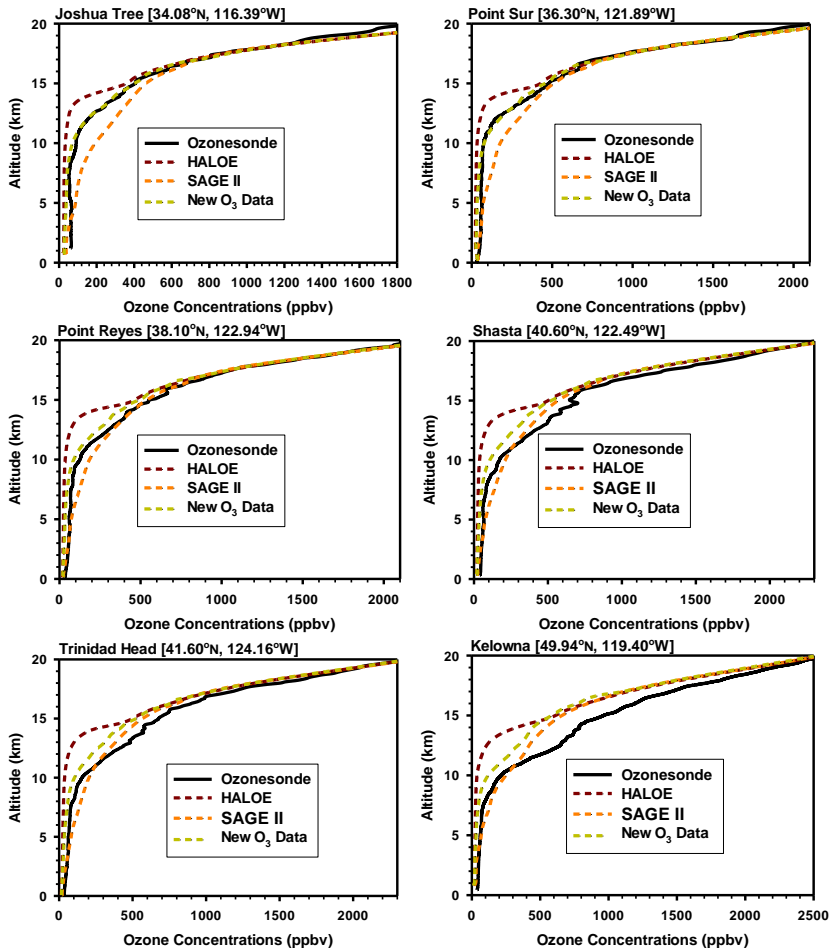

Fig. 16. Modeled ozone profiles compared with measurements at six ozonesonde sites during the 2010 CalNex field study, using data from HALOE, SAGE II, and this new ozone climatology, respectively, as the upper boundary conditions.

than is indicated by some atmospheric models (Weatherhead and Andersen, 2006). Although we note that our data extend only to 2008, Fig. 15 supports this conclusion from an independent ozone data source.

\subsection{Upper boundary conditions for tropospheric ozone simulations in chemistry models}

Previous studies have demonstrated the importance of upper boundary conditions to accurate modeling of tropospheric ozone in regional chemical forecast models (Tarasick et al., 2007; Makar et al., 2010, and references therein). The Canadian Global Environmental Multiscale meteorology model (GEM, Côté et al., 1998) has been coupled with the Modelling Air quality and CHemistry (MACH) system (Talbot et al., 2009) to operationally predict tropospheric ozone in a global uniform $1^{\circ} \times 1^{\circ}$ horizontal resolution.

The GEM-MACH global model was used for the CalNex (California Research at the Nexus of Air Quality and Climate Change) field campaign in 2010. The forecasted ozone fields during the campaign from 10 May to 20 June 2010 were evaluated by applying upper boundary conditions with three different ozone climatologies, including monthly averaged data from HALOE (HALogen Occultation Experiment), SAGE-II, and this ozone climatology for the 2000s (note that this climatology does not include ozonesonde data from 2010). For this experiment, rather than use the stratospheric and tropospheric climatologies separately, as suggested in Sect. 2.2, the complete stratosphere-troposphere climatology was used, with a dynamic adjustment of the ozone climatology to the model-predicted tropopause height, as employed by Makar et al. (2010). The ozone profiles from the three GEM-MACH global simulations were averaged from 10 May to 20 June and compared with independent ozonesondes for the same period at six CalNex campaign stations (Fig. 16). Although modeled ozone abundances above $15 \mathrm{~km}$ are generally in good agreement with observations, large discrepancies can be found in the UTLS region (8$15 \mathrm{~km}$ ) between the ozonesondes and the simulations. Using the ozonesondes as reference, the simulated ozone profiles in the upper troposphere and over the UTLS region are much improved in shape and magnitude when this climatology is used, compared to those using the satellite HALOE climatology, and in most cases show improvement over those using the SAGE climatology as well. At Joshua Tree, Point Reyes, and Point Sur, the simulation is improved from $5-15 \mathrm{~km}$ altitude, where the simulations using HALOE or SAGE climatologies tend to overestimate or underestimate ozone, respectively. At Shasta, Trinidad Head, and Kelowna (all further north), the simulated ozone profiles between $5-10 \mathrm{~km}$ are better with the new ozonesonde climatology than with HALOE climatology; but between $10-15 \mathrm{~km}$, all the model profiles are too smooth compared to the ozonesondes, suggesting that there is dynamical activity in the UTLS region that is not well-represented in the model, or that the use of single stratosphere-troposphere climatologies tends to unduly smooth the sharp change in mixing ratio at the tropopause.

\section{Summary and conclusions}

A new ozone climatology (1960s-2000s) in 3 dimensions (latitude, longitude, and altitude) has been derived based on the global ozonesonde record and trajectory statistics. The input data comprise 51898 ozone soundings at 111 stations over $44 \mathrm{yr}$ (1965-2008), obtained from the WOUDC. Forward and backward trajectories are performed for 4 days each from each sounding, driven by NCEP reanalysis data. The resulting global ozone climatology is archived monthly for five decades from the 1960s to the 2000s with a grid size of $5^{\circ} \times 5^{\circ} \times 1 \mathrm{~km}$ (latitude, longitude, and altitude). The ozone climatology is also archived yearly from 1965 to 2008 at the same horizontal and vertical resolutions.

This climatology data set is tested at 20 selected stations by comparing the actual ozone sounding profile with that derived through the trajectory technique, using the ozone soundings at all stations except the one being tested. The two sets of profiles are in good agreement with an overall correlation coefficient of 0.99 and an RMS error of $224 \mathrm{ppbv}$ 
(Fig. 3). By individual station, the correlation coefficient ranges between 0.975 and 0.998 and RMS error between 87 and $482 \mathrm{ppbv}$. The ozone climatology is also compared with two sets of satellite data, from SAGE and OSIRIS, in the stratosphere. Although agreement is generally quite good (within 10\%), there are larger biases in the UTLS, especially over mountains and in areas where ozonesonde measurements are particularly sparse.

The comparison with ozonesondes and satellite measurements (Figs. 2-9) provides us some confidence that the trajectory-mapping approach is an effective tool for interpolating sparse ozonesonde measurements. The comparison also assesses where uncertainties and limitations lie. Overall, we have more confidence in this climatology over the Northern Hemisphere than over the Southern Hemisphere, and in the middle and high latitudes than in the tropics.

At the defined grid system of $5^{\circ} \times 5^{\circ} \times 1 \mathrm{~km}$ (latitude, longitude, altitude), there are enough samples to separate decadal and seasonal variations (Figs. 12 and 13), especially after the 1990s when the SHADOZ data became available. However, there are still gaps, about $25 \%$ after the 1990s and mainly over the tropical oceans, which are interpolated with a spherical function smoothing algorithm (Fig. 13).

The ozone climatology in the long-term mean (1970s2000s) can capture the general features in the ozone distribution, such as the sharp gradient of ozone in the vicinity of the tropopause, the latitudinal variation of tropopause height, and the ozone gradient between low and high latitudes (Figs. 10 and 11). Seasonal variability of ozone in both hemispheres, as well as in the Arctic and the Antarctic, is captured (Fig. 13).

The ozone climatology shows clearly the depletion of ozone in the northern middle and high latitudes from the 1970s to the 1990s and ozone increases in the 2000s (Fig. 15). This agrees with the analyses of satellite data from TOMS and SBUV/2 by Weatherhead and Andersen (2006) and from OMI by Ziemke and Chandra (2012). Our ozone data, however, are from an independent source and a record that is twice as long as the satellite record.

This ozone climatology has been used as the initial and upper boundary conditions for a simulation of tropospheric ozone using the operational chemical forecast model at Environment Canada. The model performance is improved notably in the vicinity of the tropopause (Fig. 16).

Since the 1990s, trajectory mapping of atmospheric species has been explored with some success, suggesting that the assumptions and principles for this approach are valid. The degree of success depends on the credibility of the driving winds and available measurements of the species of interest. In addition, there are other error sources in computing trajectories, such as truncation error and interpolation error (Stohl, 1998). This study reveals the magnitude of the trajectory biases seasonally and spatially (in latitude, longitude, and altitude) at the global scale. Although zonal means of trajectory-derived ozone compare well with ozonesonde and SAGE data in the stratosphere, the comparisons at individual locations are sometimes less satisfactory. Trajectories also cannot capture sub-grid scale processes, e.g., convections at such scale. Therefore, uncertainties still remain in vertical motion of trajectories, especially over mountainous regions. In the future, this work can be improved by including more ozone measurements from different platforms, such as MOZAIC and SAGE. Different time lengths for trajectories could be employed in the stratosphere and troposphere, and with possibly better-resolved wind fields. In short, this study can provide insight for trajectory mapping of other species having similar or longer lifetime.

The advantages of this ozone climatology data set include the following: (1) it is latitudinally, longitudinally, and vertically resolved so that it can reveal longitudinal variation in the stratosphere that two-dimensional ozone climatologies cannot show; (2) it covers higher latitudes and a rather longer time period than current satellite data and some satellitebased ozone data sets, and (3) it depends on neither a priori data nor photochemical modeling and thus provides independent information and insights that can supplement satellite data and model simulations and enhance our understanding of stratospheric ozone.

Acknowledgements. The global ozone sounding data were obtained from the World Ozone and Ultraviolet Radiation Data Center (http://www.woudc.org) operated by Environment Canada, Toronto, Ontario, Canada, under the auspices of the World Meteorological Organization. We thank many whose dedication makes such a data set possible. The SAGE and OSIRIS teams are appreciated for their data sets for validation. We acknowledge the trajectory model HYSPLIT (Hybrid Single Particle Lagrangian Integrated Trajectory Model) from the NOAA Air Resources Laboratory (http://www.arl.noaa.gov/ready.html), driven by the NCEP/NCAR reanalysis data from the NOAA/OAR/ESRL PSD, Boulder, Colorado, USA, at http://www.esrl.noaa.gov/psd/. Valuable discussion with Jay Kar is appreciated. We also thank three anonymous reviewers for their helpful comments and suggestions. The first author is grateful to the Natural Sciences and Engineering Research Council of Canada (NSERC) and Environment Canada for a research fellowship. We are in the process of making the trajectory-based ozone data set available at the WOUDC website. Currently, the reader is encouraged to contact the authors for access to the data set.

Edited by: M. Dameris

\section{References}

Attmannspacher, A. and Dütsch, H. U.: International ozone sonde intercomparison at the Observatory Hohenpeissenberg, Ber. Dtsch. Wetterdienstes, 120, 1-85, 1970.

Attmannspacher, A. and Dütsch, H. U.: Second international ozone sonde intercomparison at the Observatory Hohenpeissenberg, Ber. Dtsch.Wetterdienstes, 157, 1-64, 1981. 
Baldwin, M. P. and Dunkerton, T. J.: Stratospheric harbingers of anomalous weather regimes, Science, 294, 581-584, 2001.

Bodeker, G. E., Hassler, B., Young, P. J., and Portmann, R. W.: A vertically resolved, global, gap-free ozone database for assessing or constraining global climate model simulations, Earth Syst. Sci. Data, 5, 31-43, doi:10.5194/essd-5-31-2013, 2013.

Cionni, I., Eyring, V., Lamarque, J. F., Randel, W. J., Stevenson, D. S., Wu, F., Bodeker, G. E., Shepherd, T. G., Shindell, D. T., and Waugh, D. W.: Ozone database in support of CMIP5 simulations: results and corresponding radiative forcing, Atmos. Chem. Phys., 11, 11267-11292, doi:10.5194/acp-11-11267-2011, 2011.

Côté, J., Gravel, S. , Méthot, A., Patoine, A., and Roch, M.: The operational CMC-MRB Global Environmental Multiscale (GEM) model, part I: Design considerations and formulation, Mon. Weather Rev., 126, 1373-1395, 1998.

Cunnold, D. M., Chu, W. P., Barnes, R. A., McCormick, M. P., and Veiga, R. E.: Validation SAGEII ozone measurements, J. Geophys. Res., 94, 8447-8460, 1989.

Degenstein, D. A., Bourassa, A. E., Roth, C. Z., and Llewellyn, E. J.: Limb scatter ozone retrieval from 10 to $60 \mathrm{~km}$ using a multiplicative algebraic reconstruction technique, Atmos. Chem. Phys., 9, 6521-6529, doi:10.5194/acp-9-6521-2009, 2009.

Deshler, T., Mercer, J., Smit, H. G. J., Stuebi, R., Levrat, G., Johnson, B. J., Oltmans, S. J., Kivi, R., Thompson, A. M., Witte, J., Davies, J., Schmidlin, F. J., Brothers, G., and Sasaki, T.: Atmospheric comparison of electrochemical cell ozoneso ndes from different manufacturers, and with different cathode solution strengths: The Balloon Experiment on Standards for Ozonesondes, J. Geophys. Res., 113, D04307, doi:10.1029/2007JD008975, 2008.

Draxler, R. R.: HYSPLIT4 user's guide, NOAA Tech. Memo, ERL ARL-230, NOAA Air Resources Laboratory, Silver Spring, MD, 1999.

Draxler, R. R. and Hess, G. D.: An overview of the HYSPLIT_4 modeling system for trajectories, dispersion and deposition, Aust. Met. Mag., 47, 295-308, 1998.

Eyring, V., Cionni, I., Bodeker, G. E., Charlton-Perez, A. J., Kinnison, D. E., Scinocca, J. F., Waugh, D. W., Akiyoshi, H., Bekki, S., Chipperfield, M. P., Dameris, M., Dhomse, S., Frith, S. M., Garny, H., Gettelman, A., Kubin, A., Langematz, U., Mancini, E., Marchand, M., Nakamura, T., Oman, L. D., Pawson, S., Pitari, G., Plummer, D. A., Rozanov, E., Shepherd, T. G., Shibata, K., Tian, W., Braesicke, P., Hardiman, S. C., Lamarque, J. F., Morgenstern, O., Pyle, J. A., Smale, D., and Yamashita, Y.: Multimodel assessment of stratospheric ozone return dates and ozone recovery in CCMVal-2 models, Atmos. Chem. Phys., 10, 94519472, doi:10.5194/acp-10-9451-2010, 2010.

Fioletov, V. E.: D. Ozone Climatology, Trends, and Substances that Control Ozone, Atmos.-Ocean, 46, 39-67 doi:10.3137/ao.460103, 2008.

Fioletov, V. E., Tarasick, D. W., and Petropavlovskikh, I.: Estimating ozone variability and instrument uncertainties from $\operatorname{SBUV}(/ 2)$, ozonesonde, Umkehr, and SAGE II measurements: Short-term variations, J. Geophys. Res., 111, D02305, doi:10.1029/2005JD006340, 2006.

Fleagle, R. G. and Businger, J. A.: An Introduction to Atmospheric Physics, 2nd ed., Academic, San Diego, Calif., 1980.

Forster, P. M., Fomichev, V. I., Rozanov, E., Cagnazzo, C., Jonsson, A. I., Langematz, U., Fomin, B., Iacono, M. J., Mayer,
B., Mlawer, E., Myhre, G., Portmann, R. W., Akiyoshi, H., Falaleeva, V., Gillett, N., Karpechko, A., 5 Li, J., Lemennais, P., Morgenstern, O., Oberländer, S., Sigmond, M., and Shibata, K.: Evaluation of radiation scheme performance within chemistry climate models, J. Geophys. Res., 116, D10302, doi:10.1029/2010JD015361, 2011.

Fortuin, J. and Kelder, H.: An ozone climatology based on ozonesonde and satellite measurements, J. Geophys. Res., 103, 31709-31733, 1998.

Gillett, N. P. and Thompson, D. W. J.: Simulation of recent Southern Hemisphere climate change, Science, 302, 273-275, 2003.

Hare, E. W., Carty, E. J., Fioletov, V., and Wardle, D. I.: User Guide to the WMO/GAW World Ozone Data Centre, Version 3.0, Environment Canada, 2007.

Hassler, B., Bodeker, G. E., and Dameris, M.: Technical Note: A new global database of trace gases and aerosols from multiple sources of high vertical resolution measurements, Atmos. Chem. Phys., 8, 5403-5421, doi:10.5194/acp-8-5403-2008, 2008.

Hassler, B., Young, P. J., Portmann, R. W., Bodeker, G. E., Daniel, J. S., Rosenlof, K. H., and Solomon, S.: Comparison of three vertically resolved ozone data sets: climatology, trends and radiative forcings, Atmos. Chem. Phys., 13, 5533-5550, doi:10.5194/acp13-5533-2013, 2013.

Hering, W. S. and Dütsch, H. U.: Comparison of chemiluminescent and electrochemical ozonesonde observations, J. Geophys. Res., 70, 5483-5490, doi:10.1029/JZ070i022p05483, 1965.

Holton, J. R., Haynes, P. H., McIntyre, M. E., Douglass, A. R., Rood, R. B., and Pfister, L.: Stratosphere-troposphere exchange, Rev. Geophysics, 33, 403-439, 1995.

Jacob, D. J.: Introduction to Atmospheric Chemistry, Princeton University Press: Princeton, NJ, 1999.

Jones, A., Urban, J., Murtagh, D. P., Eriksson, P., Brohede, S., Haley, C., Degenstein, D., Bourassa, A., von Savigny, C., Sonkaew, T., Rozanov, A., Bovensmann, H., and Burrows, J.: Evolution of stratospheric ozone and water vapour time series studied with satellite measurements, Atmos. Chem. Phys., 9, 6055-6075, doi:10.5194/acp-9-6055-2009, 2009.

Kalnay, E., Kanamitsu, M., Kistler, R., Collins, W., Deaven, D., Gandin, L., Iredell, M., Saha, S., White, G., Woollen, J., Zhu, Y., Leetmaa, A., Reynolds, R., Chelliah, M., Ebisuzaki, W., Higgins, W., Janowiak, J., Mo, K. C., Ropelewski, C., Wang, J., Jenne, R., and Joseph, D.:The NCEP/NCAR 40-year reanalysis project, B. Am. Meteorol. Soc., 77, 437-471, 1996.

Kent, G. S., Winker, D. M., Osborn, M. T., and Skeens, K. M.: A model for the separation of cloud and aerosols in SAGEII occultation data, J. Geophys. Res., 98, 20725-20735, 1993.

Kerr, J. B., Fast, H., McElroy, C. T., Oltmans, S. J., Lathrop, J. A., Kyro, E., Paukkunen, A., Claude, H., Köhler, U., Sreedharan, C. R., Takao, T., and Tsukagoshi, Y.: The 1991 WMO international ozonesonde intercomparison at Vanscoy, Canada, Atmos.-Ocean, 32, 685-716, 1994.

Lamsal, L., Weber, M., Tellmann, S., and Burrows, J.: Ozone column classified climatology of ozone and temperature profiles based on ozonesonde and satellite data, J. Geophys. Res., 109, D20304, doi:10.1029/2004JD004680, 2004.

Liu, G, Tarasick, D. W., Fioletov, V. E., Sioris, C. E., and Rochon, Y. J.: Ozone correlation lengths and measurement uncertainties from analysis of historical ozonesonde data in 
North America and Europe, J. Geophys. Res., 114, D04112, doi:10.1029/2008JD010576, 2009.

Liu, G., Liu, J., Tarasick, D. W., Fioletov, V. E., Jin, J. J., Moeini, O., Liu, X., Sioris, C. E., and Osman, M.: A global tropospheric ozone climatology from trajectory-mapped ozone soundings, Atmos. Chem. Phys., 13, 10659-10675, doi:10.5194/acp13-10659-2013, 2013.

Llewellyn, E., Lloyd, N. D., Degenstein, D. A., Gattinger, R. L., Petelina, S. V., Bourassa, A. E., Wiensz, J. T., Ivanov, E. V., McDade, I. C., Solheim, B. H., McConnell, J. C., Haley, C. S., von Savigny, C., Sioris, C. E., McLinden, C. A., Griffioen, E., Kaminski, J., Evans,W. F. J., Puckrin, E., Strong, K., Wehrle, V., Hum, R. H., Kendall, D. J. W., Matsushita, J., Murtagh, D. P., Brohede, S., Stegman, J., Witt, G., Barnes, G., Payne, W. F., Piche, L., Smith, K., Warshaw, G., Deslauniers, D. L., Marchand, P., Richardson, E. H., King, R. A., Wevers, I., McCreath, W., Kyrola, E., Oikarinen, L., Leppelmeier, G. W., Auvinen, H., Megie, G., Hauchecorne, A., Lefevre, F., de La Noe, J., Ricaud, P., Frisk, U., Sjoberg, F., von Scheele, F., and Nordh, L.:The OSIRIS instrument on the Odin spacecraft, Can. J. Phys., 82, 411-422, 2004.

Logan, J. A., Megretskaia, I. A., Miller, A. J., Tiao, G. C., Choi, F., Zhang, L., Stolarski, T. S., Labow, G. J., Hollandsworth, S. M., Bodeker, G. E., Claude, H., DeMuer, D., Kerr, J. B., Tarasick, D. W., Oltmans, S. J., Johnson, B., Schmidlin, F., Staehelin, J., Viatte, P., and Uchino, O.: Trends in the vertical distribution of ozone: A comparison of two analyses of ozonesonde data, J. Geophys. Res., 104, 26373-26399, 1999.

Makar, P. A., Gong, W., Mooney, C., Zhang, J., Davignon, D., Samaali, M., Moran, M. D., He, H., Tarasick, D. W., Sills, D., and Chen, J.: Dynamic adjustment of climatological ozone boundary conditions for air-quality forecasts, Atmos. Chem. Phys., 10, 8997-9015, doi:10.5194/acp-10-8997-2010, 2010.

McCormick, M. P., Zawodny, J. M., Veiga, R. E., Larsen, J. C., and Wang, P. H.: An overview of sage I and II ozone measurements, Planet. Space Sci., 37, 1567-1586, 1989.

McLinden, C. A., Tegtmeier, S., and Fioletov, V.: Technical Note: A SAGE-corrected SBUV zonal-mean ozone data set, Atmos. Chem. Phys., 9, 7963-7972, doi:10.5194/acp-9-7963-2009, 2009.

McPeters, R. D. and Labow, G. J.: Climatology 2011: An MLS and sonde derived ozone climatology for satellite retrieval algorithms, J. Geophys. Res., 117, D10303, doi:10.1029/2011JD017006, 2012.

McPeters, R. D., Labow, G. J., and Logan, J. A.: Ozone climatological profiles for satellite retrieval algorithms, J. Geophys. Res., 112, D05308, doi:10.1029/2005JD006823, 2007.

Morris, G. A., Gleason, J. F., Ziemke, J., and Schoebert, M. R.: Trajectory mapping: A tool for validation of trace gas observations, J. Geophys. Res., 105, 17875-17894, 2000.

Murtagh, D., Frisk, U., Merino, F., Ridal, M., Jonsson, A., Stegman, J., Witt, G., Eriksson, P., Jimenez, C., Megie, G., de la Noe, J., Ricaud, P., Baron, P., Pardo, J. R., Hauchcorne, A., Llewellyn, E. J., Degenstein, D. A., Gattinger, R. L., Lloyd, N. D., Evans, W. F. J., McDade, I. C., Haley, C. S., Sioris, C., von Savigny, C., Solheim, B. H., McConnell, J. C., Strong, K., Richardson, E. H., Leppelmeier, G. W., Kyrola, E., Auvinen, H., and Oikarinen, L.: An overview of the Odin atmospheric mission, Can. J. Phys., 80, 309-319, 2002.
Newman, P. A. and Schoeberl, M. R.: A reinterpretation of the data from the NASA Stratosphere-Troposphere Exchange Project, Geophys. Res. Lett., 22, 2501-2504, 1995.

Randel, W. and Wu, F.: Cooling of the Arctic and Antarctic Polar stratospheres due to ozone depletion, J. Climate, 12, 1467-1479, 1999.

Randel, W. and Wu, F.: A stratospheric ozone profile data set for 1979-2005: variability, trends, and comparisons with column ozone data, J. Geophys. Res., 111, D06313, doi:10.1029/2006JD007339, 2007.

Randel, W. J., Stolarski, R. S., Cunnold, D. M., Logan, J. A., Newchurch, M. J., and Zawodny, J. M. :Trends in the Vertical Distribution of Ozone, Science, 285, 1689, doi:10.1126/science.285.5434.1689, 1999.

Schoeberl, M. R., Ziemke, J. R., Bojkov, B., Livesey, N., Duncan, B., Strahan, S., Froidevaux, L., Kulawik, S., Bhartia, P. K., Chandra, S., Levelt, P. F., Witte, J. C., Thompson, A. M., Cuevas, E., Redondas, A., Tarasick, D. W., Davies, J., Bodeker, G., Hansen, G., Johnson, B. J., Oltmans, S. J., Vömel, H., Allaart, M., Kelder, H., Newchurch, M., Godin-Beekmann, S., Ancellet, G., Claude, H., Andersen, S. B., Kyrö, E., Parrondos, M., Yela, M., Zablocki, G., Moore, D., Dier, H., von der Gathen, P., Viatte, P., Stübi, R., Calpini, B., Skrivankova, P., Dorokhov, V., de Backer, H., Schmidlin, F. J., Coetzee, G., Fujiwara, M., Thouret, V., Posny, F., Morris, G., Merrill, J., Leong, C. P., and Koenig-Langlo, E. $\mathrm{J} .:$ A trajectory-based estimate of the tropospheric ozone column using the residual method, J. Geophys. Res., 112, D24S49, doi:10.1029/2007JD008773, 2007.

Shepherd, T. G. and Jonsson, A. I.: On the attribution of stratospheric ozone and temperature changes to changes in ozonedepleting substances and well-mixed greenhouse gases, Atmos. Chem. Phys., 8, 1435-1444, doi:10.5194/acp-8-1435-2008, 2008.

Smit, H. G. J., Sträter, W., Helten, M., Kley, D., Ciupa, D., Claude, H. J., Köhler, U., Hoegger, B., Levrat, G., Johnson, B., Oltmans, S. J., Kerr, J. B., Tarasick, D. W., Davies, J., Shitamichi, M., Srivastav, S. K., and Vialle, C.: JOSIE: The 1996 WMO international intercomparison of ozonesondes under quasi-flight conditions in the environmental chamber at Jülich, in Atmospheric Ozone: Proceedings of the Quadrennial $\mathrm{O}_{3}$ Symposium, l'Aquila, Italy, edited by: Bojkov, R. D. and Visconti, G., 971974, Parco Sci. e Tecnol. d'Abruzzo, Italy, 1996.

Smit, H. G. J., Straeter, W., Johnson, B., Oltmans, S., Davies, J., Tarasick, D. W., Hoegger, B., Stubi, R., Schmidlin, F., Northam, T., Thompson, A., Witte, J., Boyd I., and Posny, F.: Assessment of the performance of ECC-ozonesondes under quasi-flight conditions in the environmental simulation chamber: Insights from the Juelich Ozone Sonde Intercomparison Experiment (JOSIE), J. Geophys Res., 112, D19306, doi:10.1029/2006JD007308, 2007.

SPARC (Stratospheric Processes And their Role in Climate) CCMVal:SPARC CCMVal Report on the Evaluation of ChemistryClimate Models, edited by: Eyring, V., Shepherd, T. G., and Waugh, D. W., SPARC Report No. 5, WCRP-No.30, WMO/TDNo. 40, available at: http://www.sparc-climate.org/publications/ sparc-reports/sparc-report-no5/, 2010.

Stohl, A.: Computation, accuracy and applications of trajectories a review and bibliography, Atmos. Environ., 32, 947-966, 1998. 
Stohl, A. and Seibert, P.: Accuracy of trajectories as determined from the conservation of meteorological tracers, Q. J. Roy. Met. Soc., 124, 1465-1484, 1998.

Stohl, A., James, P., Forster, C., and Spichtinger, N.: An extension of Measurement of Ozone and Water Vapour by Airbus-In-service aircraft (MOZAIC) ozone climatologies using trajectory statistics, J. Geophys. Res., 106, 27757-27768, doi:10.1029/2001JD000749, 2001.

Stohl, A., Bonasoni, P., Cristofanelli, P., Collins, W., Feichter, J., Frank, A., Forster, C., Gerasopoulos, E., Gäggeler, H., James, P., Kentarchos, T., Kromp-Kolb, H., Krüger, B., Land, C., Meloen, J., Papayannis, A., Priller, A., Seibert, P., Sprenger, M., Roelofs, G. J., Scheel, H. E., Schnabel, C., Siegmund, P., Tobler, L., Trickl, T., Wernli, H., Wirth, V., Zanis, P., and Zerefos, C.: Stratosphere-troposphere exchange: a review, and what we have learned from STACCATO, J. Geophys. Res., 108, 8516, doi:10.1029/2002JD002490, 2003.

Sutton, R. T., Maclean, H., Swinbank, R., O’Neill, A., and Taylor, F. W.: High-resolution stratospheric tracer fields estimated from satellite observations using Lagrangian trajectory calculations, J. Atmos. Sci., 51, 2995-3005, 1994.

Talbot, D., Moran, M. D., Bouchet, V., Crevier, L.-P., Menard, S., and Kallaur, A.: Development of a New Canadian Operational Air Quality Forecast Model, in: Air Pollution Modeling and Its Application XIX, edited by: Borrego, C. and Miranda, A. I., Springer: Berlin, Germany, 470-478, 2009.

Tarasick, D. W., Moran, M. D., Thompson, A. M., Carey-Smith, T., Rochon, Y., Bouchet, V. S., Gong, W., Makar, P. A., Stroud, C., Ménard, S., Crevier, L.-P., Cousineau, S., Pudykiewicz, J. A., Kallaur, A., Moffet, R., Ménard, R., Robichaud, A., Cooper, O. R., Oltmans, S. J., Witte, J. C., Forbes, G., Johnson, B. J., Merrill, J., Moody, J. L., Morris, G., Newchurch, M. J., Schmidlin, F. J., and Joseph, E.: Comparison of Canadian Air Quality Forecast Models with tropospheric ozone profile measurements above mid-latitude north america during the IONS/ICARTT campaign: evidence for stratospheric input, J. Geophys. Res., 112, D12S22, doi:10.1029/2006JD007782, 2007.

Tarasick, D. W., Jin, J. J., Fioletov, V. E., Liu, G., Tompson, A. M., Oltmans, S. J., Liu, J., Sioris, C. E., Liu, X., Cooper, O. R., Dann, T., and Thouret, V.: High-resolution tropospheric ozone fields for INTEX and ARCTAS from IONS ozonesondes, J. Geophys. Res., 115, D20301, doi:10.1029/2009JD012918, 2010.

Thompson, A. M., Witte, J. C., McPeters, R. D., Oltmans, S. J., Schmidlin, F. J., Logan, J. A., Fujiwara, M., Kirchhoff, V. W. J. H., Posny, F., Coetzee, G. J. R., Hoegger, B., Kawakami, S., Ogawa, T., Johnson, B. J., Vömel, H., and Labow, G.: Southern Hemisphere Additional Ozonesondes (SHADOZ) 1998-2000 tropical ozone climatology 1. Comparison with Total Ozone Mapping Spectrometer (TOMS) and ground-based measurements, J. Geophys. Res., 108, 8238, doi:10.1029/2001JD000967, 2003a.

Thompson, A. M., Witte, J. C., Oltmans, S. J., Schmidlin, F. J., Logan, J. A., Fujiwara, M., Kirchhoff, V. W. J. H., Posny, F., Coetzee, G. J. R., Hoegger, B., Kawakami, S., Ogawa, T., Fortuin, J. P. F., and Kelder, H. M.: Southern Hemisphere Additional Ozonesondes (SHADOZ) 1998-2000 tropical ozone climatology 2. Tropospheric variability and the zonal wave-one, J. Geophys. Res., 108, 8241, doi:10.1029/2002JD002241, 2003 b.
Thompson, A. M., Witte, J. C., Smit, H. G. J., Oltmans, S. J., Johnson, B. J., Kirchhoff, V. W. J. H., and Schmidlin, F. J.: Southern Hemisphere Additional Ozonesondes (SHADOZ) 1998-2004 tropical ozone climatology: 3. Instrumentation, station-to-station variability, and evaluation with simulated flight profiles, J. Geophys. Res., 112, D03304, doi:10.1029/2005JD007042, 2007.

von Savigny, C., Haley, C. S., Sioris, C. E., McDade, I. C., Llewellyn, E. J., Degenstein, D., Evans, W. F. J., Gattinger, R. L., Griffioen, E., Kyröl ä, E., Lloyd, N. D., McConnell, J. C., McLinden, C. A., Mégie, G., Murtagh, D. P., Solheim, B., and Strong, K.:: Stratospheric ozone profiles retrieved from Limb scattered sunlight radiance spectra measured by the OSIRIS instrument on the Odin satellite, Geophys. Res. Lett., 30, 1755, doi:10.1029/2002GL016401, 2003.

Wang, H. J., Cunnold, D. M., Thomason, L. W., Zawodny, J. M., and Bodeker, G. E.: Assessment of SAGE version 6.1 ozone data quality, J. Geophys. Res., 107, 4691, doi:10.1029/2002JD002418, 2002.

Wang, L. and Waugh, D. W.: Chemistry-climate model simulations of recent trends in lower stratospheric temperatures and stratospheric residual circulation, J. Geophys. Res., 117, D09109, doi:10.1029/2011JD017130, 2012.

Wang, P.-H., Cunnold, D. M., Trepte, C. R.,Wang, H. J., Jing, P., Fishman, J., Brackett, V. G., Zawodny, J. M., and Bodeker, G. E.: Ozone variability in the midlatitude upper troposphere and lower stratosphere diagnosed from a monthly SAGE II climatology relative to the tropopause, J. Geophys. Res., 111, D21304, doi:10.1029/2005JD006108, 2006.

Wardle, D. I., Hare, E. W., Carty, E. J., and Fioletov, V. E.: The Guide to the WMO/GAW World Ultraviolet Radiation Data Centre (WUDC) Version 5.1, Atmospheric Environment Service, Environment Canada, 1998.

Waugh, D. W., Oman, L., Kawa, S. R., Stolarski, R. S., Pawson, S., Douglass, A. R., Newman, P. A., and Nielsen J. E.: Impacts of climate change on stratospheric ozone recovery, Geophys. Res. Lett., 36, L03805, doi:10.1029/2008GL036223, 2009.

Weatherhead, E. C. and Andersen, S. B.: The search for signs of recovery of the ozone layer, Nature, 441, 39-45, doi:10.1038/nature04746, 2006.

WMO (World Meteorological Organization): International meteorological vocabulary, WMO Rep. 182, World Meteorol. Org., Geneva, Switzerland, 1992.

WMO (World Meteorological Organization): Scientific Assessment of Ozone Depletion: 2002, Global Ozone Research and Monitoring Project-Report No. 47, Geneva, Switzerland, 498 pp., 2003.

WMO (World Meteorological Organization): Scientific Assessment of Ozone Depletion: 2006, Global Ozone Research and Monitoring Project-Report No. 50, Geneva, Switzerland, 572 pp., 2007.

World Climate Research Programme: SPARC/IOC/GAW Assessment of Trends in the Vertical Distribution of Ozone, Stratospheric Processes and Their Role in Climate, World Meteorol. Organ. Global Ozone Res. Monit. Proj. Rep. 43, Geneva, Switzerland, 1998.

Ziemke, J. R. and Chandra, S.: Development of a climate record of tropospheric and stratospheric column ozone from satellite remote sensing: evidence of an early recovery of global stratospheric ozone, Atmos. Chem. Phys., 12, 5737-5753, doi:10.5194/acp-12-5737-2012, 2012. 
Ziemke, J. R., Chandra, S., and Bhartia, P. K.: A 25-year data record of atmospheric ozone from TOMS Cloud Slicing: Implications for trends in stratospheric and tropospheric ozone, J. Geophys. Res., 110, D15105, doi:10.1029/2004JD005687, 2005.
Ziemke, J. R., Chandra, S., Labow, G. J., Bhartia, P. K., Froidevaux, L., and Witte, J. C.: A global climatology of tropospheric and stratospheric ozone derived from Aura OMI and MLS measurements, Atmos. Chem. Phys., 11, 9237-9251, doi:10.5194/acp11-9237-2011, 2011. 